EM

\title{
CONFIGURACIONES FAMILIARES, TERRITORIALIDAD Y RELACIONES DE PODER EN MISIONES $\left(1\right.$ ra. PARTE DEL SIGLO XX) ${ }^{1}$
}

\author{
FAMILY CONFIGURATIONS, TERRITORIALITY AND POWER \\ RELATIONS IN MISIONES \\ (1st. PART OF THE 20TH CENTURY)
}

\author{
CONFIGURAÇÕES FAMILIARES, TERRITORIALIDADE E \\ RELAÇÕES DE PODER EM MISIONES \\ (1ª. PARTE DO SÉCULO XX)
}

\begin{abstract}
Norma OVIEDO ${ }^{2}$
Resumen: Esta propuesta de trabajo pretende analizar las trayectorias de los grupos y sujetos sociales, integrados a diversos grupos de migrantes, que poblaron el Territorio Nacional de Misiones (TNM) durante la primera mitad del siglo XX. Así es que, los núcleos problemáticos focalizados desde este abordaje, relacionaran las configuraciones familiares, la ocupación territorial y las relaciones de poder implicadas entre los sujetos que desarrollan diversas acciones y actividades; en tanto ejercicio de territorialización que denotan la disputa permanente respecto de la apropiación de espacios colectivos -lo local/lo regional/lo nacional/lo internacional- y la configuración de espacios particularizados - de lo individual/de lo familiar -. Examinamos esas relaciones puntualizando el territorio misionero como parte de una región de frontera, situada entre los países de Paraguay y Brasil, integrándose a la Nueva Argentina y poblado por una diversidad de grupos de migrantes europeos y nativos. Circunscribimos la problemática planteada a partir de los siguientes interrogantes: ¿Cuál era la composición de las familias de migrantes?, ¿Cómo se produjo el proceso de ocupación territorial en el TNM?, ¿Qué actividades económicas son representativas de los grupos y, en qué casos, el alto grado de movilidad social es producto de la imposibilidad de sostenerse económicamente?
\end{abstract}

Palabras clave: Misiones - Configuraciones familiares - Territorialidad.

Abstract: This work proposal aims to analyze the trajectories of social groups and subjects, integrated to diverse groups of migrants, who populated the National Territory of Missions (TNM) during the first half of the twentieth century. Thus, the problematic nuclei focused from this approach, related family configurations, territorial occupation and power relations involved between the subjects that develop various actions and activities; as an exercise of territorialization that denotes the permanent dispute regarding the appropriation of collective spaces - local / regional / national / international - and the configuration of particularized spaces - of the individual / of the family. We examine these relationships by pointing out the missionary territory as part of a border region, located between the countries of Paraguay and Brazil, integrating into New Argentina and populated by a diversity of groups of European and native migrants. We circumscribe the problem posed from the following questions: What was the composition of migrant families? How was the process of territorial occupation in the TNM?, What economic activities are representative of the groups and, in what cases, the high degree of social mobility is the product of the inability to sustain itself economicall?.

\footnotetext{
${ }^{1}$ Investigación de doctorado. Doctorado en Ciencias Humanas y Sociales, Facultad de Humanidades y Ciencias Sociales - Universidad Nacional de Misiones (UNaM). Programa Doctorar SPU, Res. SPU No $1428 / 12$ y $1543 / 13$.

${ }^{2}$ Mestre em Historia Iberoamericana (PUCRS-Pontificia Universidade Católica de Rio Grande do Sul), Licenciada en Historia y Profesora en Historia c/o en Ciencias Sociales (UNaM-Universidad Nacional de Misiones).
} 
Keywords: Misiones - Family configurations - Territoriality

Resumo: Esta proposta de trabalho tem como objetivo analisar as trajetórias de grupos e sujeitos sociais, integrados a vários grupos de migrantes que habitaram o Território Nacional de Misiones (TNM) durante a primeira metade do século XX. Dessa forma, os núcleos problemáticos enfocaram a partir dessa abordagem, configurações familiares relacionadas, ocupação territorial e relações de poder envolvidas entre os sujeitos que desenvolvem diversas ações e atividades; como um exercício de territorialização que denota a disputa permanente sobre a apropriação de espaços coletivos - o local / o regional / o nacional / o internacional - e a configuração de espaços particularizados - do indivíduo / da família -. Examinamos essas relações apontando o território missionário como parte de uma região de fronteira, localizada entre os países do Paraguai e Brasil, integrando-se à Nova Argentina e povoada por uma diversidade de grupos de migrantes europeus e nativos. Circunscrevemos o problema das seguintes questões: Qual a composição das famílias migrantes? Como foi o processo de ocupação territorial no TNM?, Quais atividades econômicas são representativas dos grupos e, em que casos, o alto grau de mobilidade social é o produto da incapacidade de se sustentar economicamente?

Palavras chave: Misiones - Configurações familiares - Territorialidad

\section{Introducción: En el hacer de las trayectorias para indagar sobre la territorialidad de las acciones y relaciones de y entre las familias durante la colonización}

En este trabajo se pretende analizar las trayectorias de los grupos y sujetos sociales, integrando diversos grupos de migrantes, que poblaron el Territorio Nacional de Misiones (TNM) durante la primera mitad del siglo XX. Así es que, los núcleos problemáticos focalizados desde este abordaje, relacionan las configuraciones familiares, la ocupación territorial y las relaciones de poder implicadas entre los sujetos que desarrollaron diversas acciones y actividades; en tanto prácticas de territorialización que ponen de manifiesto la disputa permanente respecto de la apropiación de espacios colectivos -lo local/lo regional/lo nacional/lo internacional $-\mathrm{y}$ la configuración de espacios particularizados - de lo individual/de lo familiar -.

Examinamos esas relaciones puntualizando al territorio misionero, como parte de una región de frontera situada entre los países contiguos de Paraguay y Brasil, integrándose al Estado Nacional Argentino y poblado por una diversidad de grupos de aborígenes, negros, criollos e inmigrantes. Atendiendo a la cuestión explicitada anteriormente, es que circunscribimos la problemática planteada a partir de los siguientes interrogantes: ¿Cómo se produjo el proceso de ocupación territorial en relación al asentamiento de los grupos de migrantes en el Territorio Nacional de Misiones? Reconociendo espacios particularizados de asentamiento permanente y otros de carácter transitorio, ¿Cuál era la composición de las familias de migrantes? Considerando integrantes, franja etaria, orígenes, actividades, estado civil, etc., y; finalmente ¿Qué actividades económicas son representativas de los grupos? En relación a la formación de asociaciones de particulares y, en qué casos, el alto grado de movilidad social es producto de la imposibilidad de sostenerse económicamente.

La fuente principal para este análisis procede de una base de datos propia, constituida por un conjunto aproximado de 250 biografías de pobladores del TNM publicadas en el último capítulo en la obra de Eric Tschumi $(1948)^{3}$. Desde las breves descripciones que aporta esta fuente podemos visualizar que existe una población asentada en el territorio misionero al momento en que ingresan los inmigrantes europeos; quienes son atraídos por la política

\footnotetext{
${ }^{3}$ Tschumi, Eric. Tierra Colorada. Síntesis agraria, industrial, comercial, cultural, turística y biográfica del Territorio Nacional de Misiones. Bs. As., Talleres Gráficos Alemann y Cia. S.A.G.I, 1948. Listado de biografías de pobladores del TNM, en Capitulo IX titulado: "Forjadores de Misiones”, pág. 303.
} 
inmigratoria del estado argentino y por la acción estatal de las empresas de particulares. La publicación de Tschumi apuesta a ofrecer información a los gobernantes bonaerenses sobre la situación socio-económica y cultural de un espacio fronterizo que, al igual que otros localizados al norte y al sur del núcleo central compuesto por las provincias argentinas, eran tierras fiscales/nacionales habitadas por grupos de aborígenes y de criollos; territorio, recursos y habitantes sobre los cuales el Estado profundizaba la observación y el reconocimiento e imponía las nuevas reglas para la inserción y organización. Es por y para ello que, también, otros produjeron este tipo de obras, por ejemplo, la del periodista e historiador Jorge Newton $(1951)^{4}$ que como funcionario del gobierno peronista escribió un libro a manera de informe minucioso sobre lo que ocurría en los diversos pueblos misioneros durante este medio siglo; es probable, entonces que Tschumi, sobre el que no existen referencias, tuviera la misma intención ya que su texto se constituye, en parte, de una recopilación de artículos producidos por autores misioneros o que al menos viven en Misiones a los que incluye la información de su propio relevamiento. Lo distintivo del trabajo de Tschumi es el capítulo 3 que se compone de las breves biografías de pobladores, constituida por grupos de criollos, de inmigrantes e hijos de inmigrantes.

El análisis de la información recogida desde las biografías nos permitió, en términos generales, organizar una base de datos para observar los modelos sociológicos habituales sobre la constitución de las familias; basándonos en el cruce de las siguientes variables: procedencia, ocupación, edad, estado civil, cantidad de hijos, etc. y, en términos específicos, la relación de esos datos, nos habilito el reconocimiento de vínculos interpersonales, laborales y asociacionales como, así también, la indagación de las actividades relevantes en los pueblos y sus poblaciones locales. Es decir, que desde una perspectiva micro y a una escala de observación acotada a las configuraciones de familias y su trayectoria particularizada, reconstruimos la trama de relaciones sociales de una sociedad en formación; constituida con grupos étnicos preexistentes y foráneos.

\section{Desarrollo. Territorios y territorialidades: establecidos y outsiders en el proceso de colonización/poblamiento en la región de frontera}

El territorio de la actual Provincia de Misiones históricamente ha integrado la Región de Frontera, compuesta por Provincias, Estados y Departamentos de Argentina, Brasil y Paraguay respectivamente; esta es una región que se extiende más allá de los límites de los Estados - Nación y que la visibilizamos en torno a la espacialización/territorialización de relaciones y prácticas sociales constituidas sobre un basamento histórico cultural compartido. En ese sentido, las regiones "son espacios de encuentros e intercambios entre pueblos que constantemente transcienden esos límites porque poseen un pasado común" (OVIEDO, 1993: 27 citado en ARELLANO Y OVIEDO, 2017).

\footnotetext{
${ }^{4}$ Jorge Newton (1906-1978) fue un prolífico autor que en la década del ’30 y por la Editorial Claridad, publicó novelas de contenido social como En marcha, Avanzada, La Andanza gris y Tierra virgen. Durante los años peronistas escribió Perón, el visionario (1955), una biografía laudatoria del líder justicialista y Clase media (1949); esta última obra que trataba sobre el impacto del peronismo en la pequeña burguesía y que, inclusive, fue llevada al teatro. Fue Director de la Revista Mundo Peronista, aunque ni él ni sus redactores aparecían con sus verdaderos nombres: algunos de los artículos y notas estaban firmados con seudónimos (Silo Gismo, Elicás, A De Menos, A De Mas, Loco Noce, El Observador Peronista, Fe, Justicialista, Mas de Capirote, Verissimus), otros con iniciales (O. R., J. G., J. C. M., E. S., J. N., M. A. D., E. B., E. P. O.), y otros no llevaban ni siquiera eso. (Panella, Claudio: Mundo Peronista (1951-1955): "Una tribuna de doctrina". Disponible en:http://www.elortiba.org/old/pdf/Panella_Mundo_Peronista.pdf 7/1/2019).
} 
En el transcursodel siglo XIX, el territorio misionero fue disputado por los Estados fronterizos de Paraguay y de Brasil pero, también, por algunas de las provincias argentinas de Entre Ríos, Santa Fe y Corrientes; situación que impuso un escenario altamente militarizado y de gran inestabilidad político-administrativa. Sin embargo, a fines de siglo, estas tierras se integraron definitivamente al Estado Nacional Argentino, constituyéndose el Territorio Nacional de Misiones (1884) $)^{5}$.En ese contexto, los productos aportados por una economía de enclave, básicamente sostenida en el frente extractico ${ }^{6}$, que proveía de madera nativa y de yerba mate silvestre, insertaron a Misiones al mercado nacional, en el marco de una Argentina que definía un perfil económico agroexportador, privilegiando la producción primaria y las manufacturas. La re-organización del mercado nacional promovía la regionalización de las economías del denominado interior e integraba sus producciones al circuito económico conectado a las redes de circulación comercial internacional.

A partir de ese momento, las políticas estatales de colonización enfatizaron la reocupación territorial de los antiguos pueblos misioneros y promovieron la formación de nuevos poblados, a través de políticas que fundamentalmente fomentaron la inserción de los inmigrantes europeos a la región. Convertir estos espacios de tierras fiscales en tierras productivas fue el objetivo de los sucesivos gobiernos territorianos y nacionales, por ello se impulsó el poblamiento y el asentamiento de inmigrantes, a quienes se consideraba aptos comomano de obra para el trabajo en las actividades agrícolas. Es decir, que el ideal del inmigrante que se esperaba llegase al país y a la regiónera "alguien asociado con el trabajo y, como objeto deseable, con la agricultura" (DEVOTO, 2009, p. 34),inmigrantes que durante el proceso de colonización/adaptación construirían los vínculos de sociabilidad requeridos para integrarse a la sociedad argentina; en territorios situados, según las consideraciones oficiales, en los confines de la nación y que por su extensión y reconocido despoblamiento eran concebidos, por los funcionarios instalados en Buenos Aires, como zonas caratuladas como "desiertos" o, más bien, lugares “inexistentes”(DEVOTO, 2003, pp. 229).

A fines del siglo XIX y primeras décadas del XX, tanto el país, en general, como las Provincias y los Territorios Nacionales, en particular, estaban atravesados, en proporciones relativas, por la presencia contundente de la inmigración europea; no obstante este aluvión poblacional se asienta en territorios ocupados por grupos de aborígenes, de negros y de mestizos/criollos. Los llamados Territorios Nacionales surgieron en las actuales regiones patagónica, chaqueña y misionera ${ }^{8}$, pobladas, fundamentalmente, por aborígenes que, en su

\footnotetext{
${ }^{5}$ Finalizada la Guerra de la Triple Alianza (1870) el río Paraná fijo definitivamente el límite entre Paraguay y Argentina, quedando el territorio de la actual Provincia como jurisdicción argentina, aunque permaneció gobernada por autoridades correntinas. Ante la Federalización, inclusión al Estado Argentino, los dirigentes correntinos autorizaron una rápida venta de tierras misioneras en grandes fracciones de 25 leguas cuadradas y, de este modo, casi dos tercios del territorio pasó a pertenecer a grandes propietarios correntinos, entre otros Antonio B. Gallino (Gdor. de Ctes.) y Rudecindo Roca (1er. Gdor. territoriano y hno. del Pte. Julio A. Roca). En ese transcurso de tiempo (1870- 1881) el territorio se caracterizó por una gran movilidad social definida por asentamientos transitorios, con población nativa de aborígenes y criollos -estos últimos: correntinos, paraguayos y brasileños-.

${ }^{6}$ A finales del siglo XIX y comienzos del XX, se formaron obrajes para la extracción de madera nativa y yerba mate en el Alto Paraná, a ambas márgenes del río. Los manchones de yerbales nativos, en algunos puntos de la región, superaban los 18 y 20 metros de altura y la extracción de los mismos fue concedida, por zona a ciertos empresarios. Un problema conflictivo pero habitual fue la tala desordenada de los árboles, en todo tiempo y lugar; lo que provoco un proceso de destrucción paulatino de los yerbales silvestres.

${ }^{7}$ La ley de inmigración y colonización de 1876 consideró como sinónimos los términos de inmigrante y extranjero pero solamente para el caso de aquellos que ingresaron "en buques de vapor o de vela" provenientes de los "puertos de Europa o de los situados de cabos afuera"; además de esta primera caracterización, el inmigrante era aquel que ingresaba al país en segunda o tercera clase (Devoto, 2009: 31-32).

"Las regiones tanto nordeste como patagónica se constituyeron en parte de la República Argentina como Territorios Nacionales (1884 - 1955), al ser integrados al Estado junto al grupo de las catorce Provincias de la
} 
mayoría, fueron aniquilados durante las expediciones militares; o que migraron/desertaron hacia otros lugares o se integraron al trabajo a través de actividades para las que tenían habilidades y capacidades. En el caso de la región misionera, las ideas de "desierto" o de "espacio vacío", que aludía al período de fuerte ingreso inmigratorio a la región, fue totalmente desmitificada mediante algunas investigaciones historiográficas (OVIEDO,1994, 2014, 2018; SCHVORER, 2011, LEVINTON y SNIHUR, 2015), que demostraron la presencia continua de grupos y familias de guaraníes y de criollos habitando en el territorio de los ex - pueblos jesuíticos, fueron compulsivamente integrados al proceso de mestizaje implementado por el Estado Nacional argentino.

En este contexto, de integración territorial, se define la re-ocupación de las tierras "disponibles" a fin convertirlas en espacios productivos mediante la planificación de la colonización", que efectivizada desde la acción estatal y desde las empresas privadas el proceso inmigratorio. Sin embargo, paralelamente a ese proceso planificado oficial y estatalmente, transcurre una movilidad social espontánea en la región de frontera, sustentada por la circulación de una población integrada por familias de aborígenes y grupos de negros y otra criolla/mestiza, clasificada desde las nacionalidades como de orígenes paraguayo y brasileño; los primeros ocupando tierras deshabitadas y los últimos adquiriendo propiedades, sin dueño o pertenecientes a propietarios ausentistas, situaciones que automáticamente, ubicaba a unos como intrusos y a otros como propietarios o potenciales propietarios.

Bajo ese panorama, el considerar la heterogeneidad como característica distintiva a la composición social de la sociedad regional refiere no solo a la diversidad de inmigrantes que la integro, sino que, esa pluralidad, se construye sobre la base de los grupos preexistentes al momento en que se produce la colonización. Es de destacar, esta aclaración puesto que en la mayoría de los trabajos sobre el tema, el concepto de heterogeneidad armoniza y se fundamenta, específicamente, en la variedad de las comunidades de inmigrantes; sin embargo nuestra lectura orienta a entender/comprender ese hecho enfatizando la complejización de la estructura social y, por lo tanto, la multiplicación de la heterogeneidad social. Esta mirada registra, tanto la existencia de sectores dispersos de aborígenes, negros y criollos como la inclusión de los múltiples grupos y familias de inmigrantes, los últimos insertos según márgenes de movilidad socio-territorial internacional/nacional/regional/local; es decir, contextualizadas en trayectorias de alcance global: provenientes de Europa, de otras provincias argentinas y de estados y departamentos de los países vecinos y, a su vez, de movilidades en/entre los espacios locales/pueblos misioneros.

El proceso colonizador va acompañado del proceso de poblamiento, no obstante la colonización no se instituye como un proceso independiente sino que está asociada a la proliferación de los centros urbanos, a la diversificación económica y a la movilidad social planificadas (MIGUEZ en DEVOTO y MADERO, 1999); mientras que el poblamiento espontáneo, si bien incide en esos aspectos, más bien motoriza y acrecienta la movilidad social en torno a las actividades económicas y la inserción laboral incluyendo, temporaria o definitivamente, a los sujetos y familias de migrantes e inmigrantes en las poblaciones locales. En los TN, el establecimiento permanente de la población en determinados lugares implicaba la formalización de los centros urbanos, y ello generaba la movilización de la nueva

zona centro y noroeste del país. La actual Provincia de Misiones fue uno de esos Territorios Nacionales, incorporados por el gobierno central como espacios territoriales nuevos y culturalmente fronterizos (geográficamente aislados, poblados por aborígenes y extranjeros, con límites imprecisos, etc.) y, por ende, en proceso de inclusión a la soberanía estatal y a la ciudadanía nacional.” (OVIEDO y ALCARAZ, 2014: 95).

9 “ “...] el poblamiento, a diferencia de la colonización, no es planificado, es un proceso de asentamiento de un grupo humano en un sitio para habitar o trabajar en él. De modo que un territorio puede estar poblado, ya sea por una acción colonizadora o por una ocupación espontánea..." (GALLERO, 2008). 
generación de hijos de inmigrantes hacia otros lugares que se constituían en poblados intermedios - entre lo más urbano y lo más rural -.

El TNM era un territorio fronterizo mayoritariamente ruralizado, donde tanto las ciudades como los poblados se originaban en una colonia y, pasado un tiempo relativo, esta se transformaba, debido al crecimiento y la estabilidad de la población, en un espacio urbanizado y así, sucesivamente. De esta forma, continuamente emergían nuevas colonias que eran aledañas a los pueblos y el proceso se renovaba repetidamente en el transcurso de una generación a otra $\mathrm{y}$, en ese contexto, la disponibilidad de tierras, la multiplicación de las actividades económicas y el abanico de posibilidades laborales eran factores que se combinaban y definían la orientación de la expansión territorial; constituyéndose en atractivos suficientes para que los pobladores, tanto extranjeros como nativos, se movilizaran procurando asentarse y convertirse en propietarios de las tierras.

Sin embargo, la tierra era un bien a la que podían acceder los inmigrantes y los criollos blancos o mestizos, excluyéndose, definitivamente, a los aborígenes y negros de esta posibilidad. Lo mismo ocurría con el acceso al campo laboral, debido a que la inserción de los inmigrantes estaba prevista existiendo una variedad de ocupaciones y profesiones, actividades comerciales, de servicio y de comunicación, etc. en las que la mano de obra de los estos era considerada necesaria y requerida en las zonas más urbanizadas; además de las labores agrícolas y ganaderas en chacras y campos propiamente características de las zonas rurales. Como es de observar, las alternativas de inserción laboral presentaba un abanico de posibilidades, selectivas en tanto capacitación profesional, ocupaciones y existencia de espacios laborales, sin embargo para los aborígenes y los negros la oportunidad de acceso laboral y producción de ingresos, era muy reducida en el territorio misionero puesto que al ser un ámbito mayormente rural solo les habilitaba, por un lado, para unos cuantos la inserción como mano de obra barata y sobre explotada; en tanto peones no calificados y en calidad de asalariados parcial o totalmente $\mathrm{y}$, por otro lado, para unos pocos guaraníes artesanos la inclusión al circuito comercial vendiendo, a bajos precios, sus productos artesanales.

Respecto de los datos que las fuentes nos ofrecen para analizar el proceso colonizador, por un lado, los resultados del Censo Nacional de Población (1947) que sirviera de base para el Plan Quinquenal (1950) y la elaboración de la cartografía respectiva, nos provee de una imagen sincrónica acerca de la dinámica del proceso de ocupación y nos permite identificar, radiográfica y diferenciadamente, los ámbitos más urbanizados de aquellos más ruralizados en el territorio misionero; atendiendo a las dimensiones de las unidades político-administrativas y en relación con la cantidad de habitantes. Entre los primeros encontramos los Departamentos de Capital, San Javier y Candelaria a los que proseguían Iguazú, Cainguás, Concepción de la Sierra y Apóstoles; hasta culminar en las zonas rurales con bajo porcentaje demográfico, Departamentos de Frontera, Guaraní y San Pedro - situados hacia el nordeste provincial -. 
Mapa $\mathbf{N}^{\circ}$ 1: Población del Territorio Nacional de Misiones

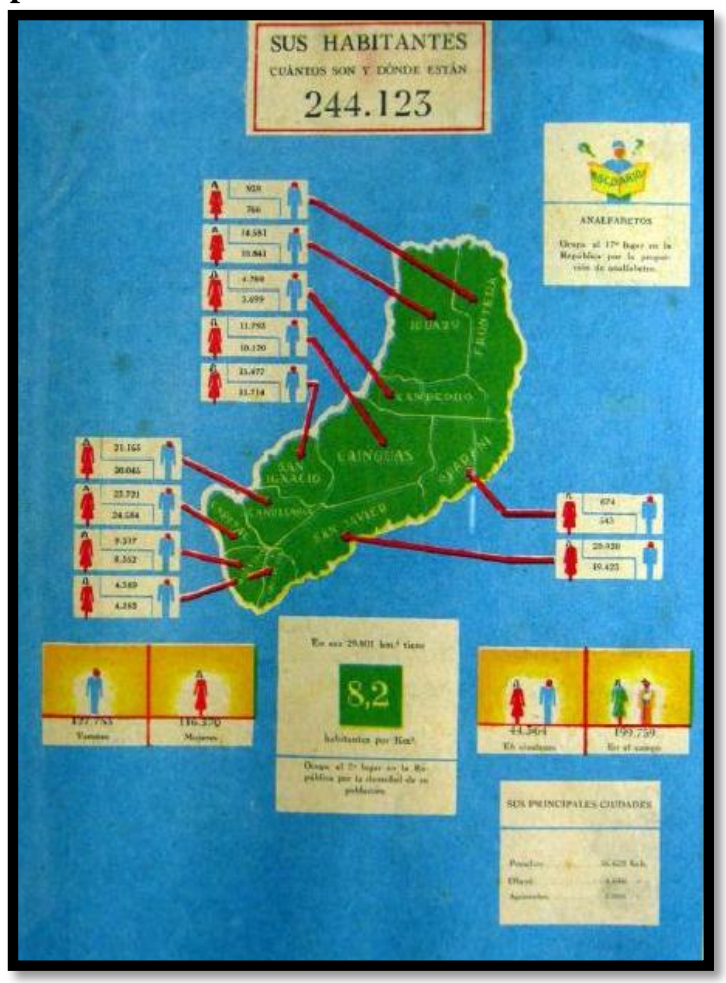

Fuente: Plan Quinquenal (1950).

Por otro lado, de la muestra relevada por Tschumi, obtenemos un panorama diacrónico de la movilidad en el TNM, por familias de pobladores migrantes, (aborígenes, criollos e hijos de inmigrantes), de inmigrantes fronterizos (de Brasil, Paraguay y Uruguay y algunos latinoamericanos, del Caribe y de $\mathrm{Cuba}$ ), de inmigrantes migrantes dentro del país y, fundamentalmente, de inmigrantes europeos y, una minoría, de asiáticos. Los grupos de aborígenes no aparecen estadísticamente registrados puesto que una parte se hallaba mestizada y aculturada, portando lengua, vestimenta y costumbres del sector criollo, e incorporada a la sociedad regional/local con nombres y apellidos blanquizados y, otra parte, los que aún conservaban su cultura, no fue localizada debido a la movilidad constante como modo de vida y el asentamiento en lugares inhóspitos y lejanos (SCHIAVONI, OVIEDO y JAQUET, 2001).Sin embargo, el relevamiento de Tschumi registra referencias aportadas por algunos inmigrantes sobre tribus de guaraníes que habitaban en territorios fronterizos y con los que compartían actividades de caza y pesca ${ }^{10}$, otros guaraníes son aludidos por naturalistas/aficionados que recolectan/coleccionan sus objetos culturales para estudios antropológicos $^{11}$ o como material de museos $^{12}$ mientras que un sector de guaraníes son insinuados, a partir de la ausencia, desde la escasez de brazos como peones en las chacras de algunos inmigrantes.

\footnotetext{
${ }^{10}$ Biografía de José Faubel, australiano nacido en 1901, establecido en Eldorado es el más entusiasta aficionado a la pesca y la caza, empleando la mayor parte de su tiempo libre en recorrer los montes; es amigo de una tribu de indios en Paraguay. A los que periódicamente visita organizando cacerías. Está preparando un libro que llevara por título: "Veinte años de caza y pesca en Misiones". (TSCHUMI, 1948).

${ }^{11}$ Biografía de Ernesto Rodolfo Mayntzhusen, nacido en Bs. As. en 1898, vive en Eldorado. Hijo de un famoso naturalista, poseedor de una vasta cultura, sintiendo afición por los estudios científicos, se dedica con gran entusiasmo a la antropología, especializándose en lo que se relaciona con los indios paraguayos. (TSCHUMI, 1948).

${ }^{12}$ Biografía de Pedro Pablo Monzón, posadeño nacido en 1898. Aficionado a coleccionar piezas indígenas, ha llegado a formar un museo en el que se encuentran algunos objetos de valor histórico por los que se interesan la Dirección de Parques Nacionales y el Museo de la Plata. (TSCHUMI, 1948).
} 
De esta manera, reconocemos las relaciones entre indios e inmigrantes, inscriptas, básicamente, en una red de vínculos que denuncian relaciones interpersonales esporádicas, de "amistad" o de conocimiento circunstancial, para el ejercicio de actividades de recreación y/o de reconocimiento de ausencias a falta de nativos peones; que en otra época existía. El relato de los inmigrantes, portante intermediario de la voz de los otros, visibiliza una territorialización de la presencia aborigen, según intereses particularizados, compañero de cacería, objeto de estudio y mostración de vestigio, mano de obra, etc.; localizándolos en ámbitos rurales fronterizos entre los estados nacionales, zona costera paraguayo-argentina frente al pueblo de Eldorado, y fronterizo entre espacios de economía extractiva-agrícola, zona central de Misiones; más precisamente la colonia Yerbal Viejo y actual pueblo de Oberá $^{13}$.

Figura $\mathbf{N}^{\circ}$ 1: Presencia aborigen
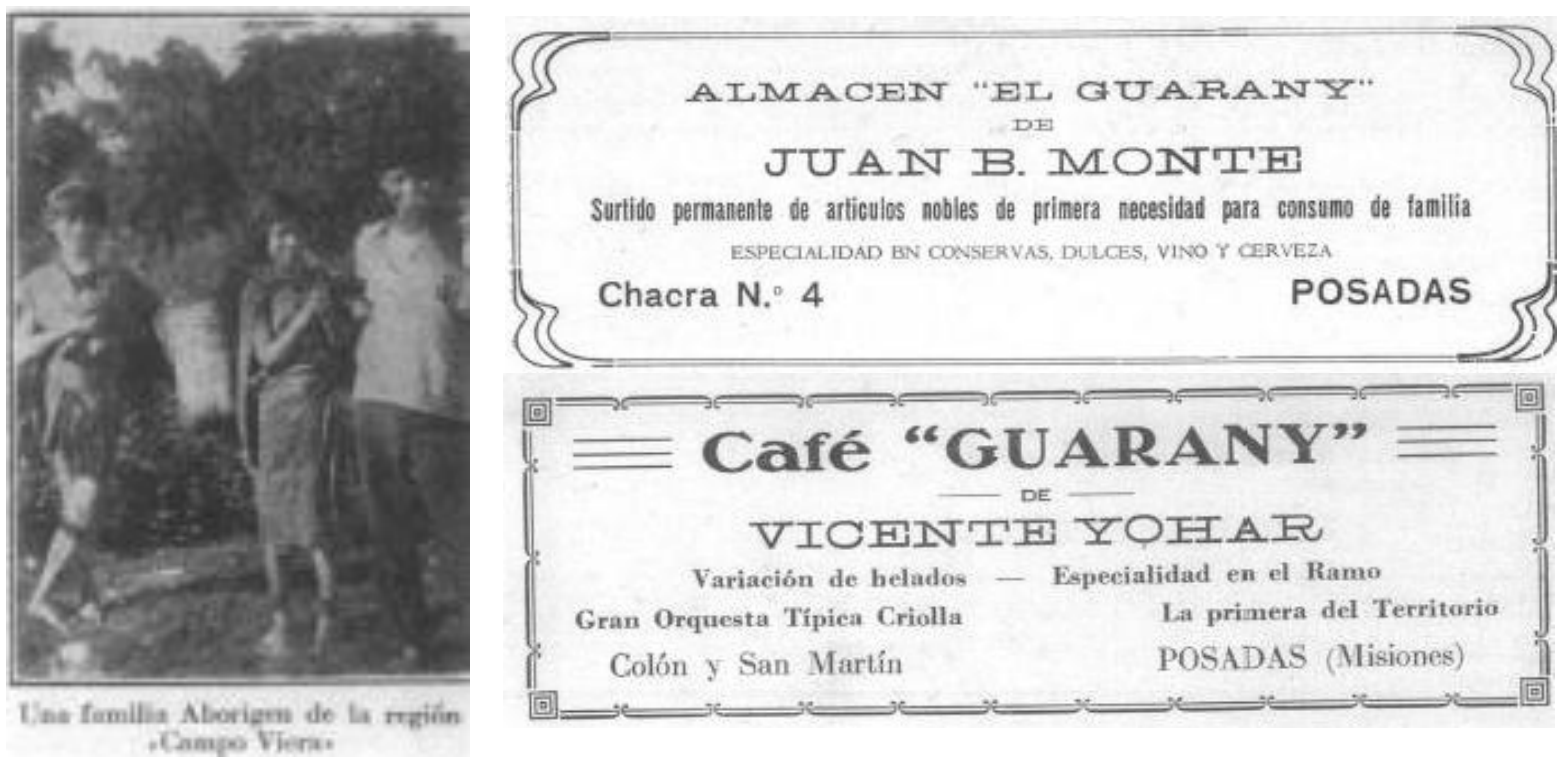

Fuente: Sosa, Atanasio. Guía General de Misiones. Posadas, 1923.

No obstante, otras fuentes de época, como los anuarios ${ }^{14}$, aportan información muy tangencial sobre los guaraníes ubicándolos en espacios fronterizos entre Paraguay y Argentina como, también, en algunos pueblos y en la capital territoriana, Posadas. Aparecían tanto en las publicidades, por ejemplo en los nombres de cafés y farmacias., como en la oferta de productos artesanales en determinados comercios (Figuras 1 y 2).Según las fechas de publicación de los anuarios, 1923 y 1943, podemos inferir que la presencia de los guaraníes, ha sido continúa en toda la región, zonas fronterizas, pueblos recónditos y áreas urbanizadas, ya que el anuncio de la casa de productos artesanales asigna la autoría de los mismos como "Trabajos de indios de la región".

\footnotetext{
${ }^{13}$ Biografía de Einar Nilsson, nacido en Suecia en 1900, de Yerbal Viejo. "No conseguía gente para trabajar, y los pocos que había eran en su mayor parte malevos huidos del Brasil y Paraguay. Hasta 1920 solo se conseguían indios para el trabajo. Pero afortunadamente las cosas fueron cambiando". (TSCHUMI, 1948).

${ }^{14}$ Los Anuarios o Almanaques, también llamados Guías Generales de Misiones (1923, 1938, 1943) se constituyen en fuentes de información que aportan datos particularizados sobre la historia local/es del TNM, sus destinatarios eran los hombres de negocios y viajeros y, por ello fueron, pensadas para promocionar los recursos económicos y turísticos a fin de promover diversas actividades y negocios en los diversos pueblos. Una de estas guias expresaba: "Sera un consejero para el agricultor, para el industrial, para el comerciante, para el turista y para todo viajante, proporcionándoles a cada uno de ellos los más mínimos detalles.” (1938).
} 
Figura $\mathbf{N}^{\circ}$ 2: Publicidades y aborígenes

"EI CaCIqUe"
-de-
FELIX ECHEVERRIA
Cueros y productos de animales salvajes-
Trabajos de indios de la región - Mates paraguayos -
Bombillas de oro y plata
Yerbas medicinales - Te "Pachamama"
Sarmiento y Buenos Aires - Posadas

Fuente: Bordón, Arturo y Valdovinos, Elías: Guía General de Misiones. Descripción geográfica, Histórica, Política, Económica, Cultural y Social de Misiones. Posadas, Ed. América, 1943.

Sin embargo, desde el análisis de estos registros notamos la parcialización de la información que unificada y relacionada en sus datos resultan, en parte, contradictorias en sus argumentaciones, pues presentan indicios tanto de la desaparición como de la existencia de los aborígenes ${ }^{15}$; de la misma manera se vislumbran conjeturas acerca de las características del territorio misionero en tanto representaciones sociales propias de la sociedad argentina de esa época, aseverando que estas tierras son selváticas, pobladas por indios y ocupadas por animales salvajes. Esa mirada es, la que en parte, Tschumi concebía antes de visitar Misiones y la que intenta desactivar estando en el territorio, sosteniendo que "... sigue siendo, para los que están lejos, la tierra legendaria de los mensúes, los tigres y las cataratas"; sin examinarlos a partir de sus rasgos físicos, idioma y costumbres ya que muchos de esos trabajadores/ mensúes del Alto Paraná, son reconocidos y registrados como correntinos, paraguayos y brasileños; dato que él toma mecánicamente como información relevada en los capítulos de su obra.

Como bien anticipáramos, otros pobladores que transitaban la región eran los negros, no mencionados en censos ni anuarios y tampoco en las biografías de Tschumi, sin embargo, la existencia y persistencia de este grupo es posible reconocerlas, parcializada y fragmentariamente, desde fuentes documentales, referencias de criados utilizados como servicio doméstico, gráficas, fotografías antiguas en álbumes familiares, y rasgos físicos observables en familias que conforman la sociedad local/regional aún en la actualidad. Son escasas y recientes las investigaciones sobre los afro-descendientes, aunque ellas atestiguan, indiciariamente, una masiva participación de estos grupos en la composición de los ejércitos revolucionarios; componiendo la tropa que, intermitentemente, se enfrentaron en la región (1810/70). Durante la guerra de la Triple Alianza (1865/70), contienda que se desarrolló y tuvo implicancias local/regional/nacionales, un grupo de afro-descendientes desertó de las filas se asentó en territorio misionero; en una zona denominada "Sierrinas" de San José, San Juan de la Sierra o San Isidro. En tanto otros grupos entraron, expulsados por revueltas del Estado de Rio Grande do Sul, por el paso de Garruchos, el Paso San Isidro, Puerto Azara y el

\footnotetext{
${ }^{15}$ Biografía de Ricardo Seoane, nacido en Rosario en 1901. "Suponía que Misiones solo encontraría indios, y después de un interminable viaje en carro por caminos imposibles encontré que aquí todos eran, rubios". "Me traje, continua contando, 2.000 balas de Winchester y apenas si encontré consejos, pues en 23 años solo vi un tigre". "Así conocemos Misiones los argentinos". (TSCHUMI, 1948).
} 
Paso de Itacaruaré y se dispersaron por las estancias o establecimientos agrícolas ganaderos; trabajando como peones y/o personal de servicio.

En síntesis, en la costa del río Uruguay nos encontramos con una población afrobrasileña proveniente de Brasil y en la costa del río Paraná a una población afro-guaraní proveniente de Paraguay. Recientemente, se construyeron registros fotográficos y testimoniales sobre algunas de estas familias de negros, analizando álbumes familiares y recopilando voces mediante entrevistas, además se relevaron referencias de vestigios arqueológicos en los cementerios de los pueblos y del uso de léxicos en la comunidad de hablantes (SALAS en LAMBORGHINI y otros, 2017). Mientras, en los estudios de colonización realizados como informes de investigación, artículos científicos y tesis de grado en los centros académicos de la región (UNaM - UNNE, entre otros) las referencias son casi nulas; en acotadas líneas solo aparece mencionada la existencia de una "Picada Africana"16 (SCHIAVONI, 2002, SCHIAVONI y GALLERO, 2017) sobre la que no surge ningún interrogante que la asocie a la presencia de los negros.

Y otros, entre los establecidos, son los criollos, reconocidos en el conjunto de familias de correntinos, las que están representadas por siete familias en la obra de Tschumi; no obstante esta presencia no se constituye en un dato sorprendente. La migración y el establecimiento de pobladores correntinos fue observada durante el siglo XIX en general $^{17}$ (FERNÁNDEZ RAMOS 1928; CAMBAS, 1945; ETORENA y FREAZA, 2010), y durante el período de la ocupación paraguaya (1820 - 1845), específicamente, poblando la zona de campo en el sur de la actual provincia de Misiones; conformando parte del grupo de "familias decentes" dedicadas a la producción ganadera para abastecer a los ejércitos. Cuando sobrevino la guerra estas debieron retirarse a sus lugares de orígenes o asentarse en el Paraguay (OVIEDO, 1994, 2014). Sin embargo, durante los años de enfrentamiento (1865/70), algunos correntinos constituyeron el grupo de proveedores/abastecedores de las tropas, los denominados viandantes que, al finalizar la contienda, se establecieron en territorio posadeño. De hecho, hacia fines del siglo, Posadas pertenecía a la jurisdicción correntina hasta que fuera intercambiada por la localidad misionera de San Carlos; posicionándose como Capital (1884) del entonces TNM.

Entonces, a fines del siglo XIX, este nuevo aluvión de familias correntinas constituyo, al igual que un conjunto de familias de brasileños también asentadas en Posadas al finalizar el conflicto armado, un sector de la élite local y, por ello, fueron destacadas en las obras de los primeros historiadores locales; quienes sostuvieron que "La sociedad de Posadas no se formó, como alguien cree, con aventureros y vagabundos de origen desconocido, lo fue con familias de principios, de reconocida moralidad, procedentes de Santo Tomé, San Borja, Alvear, La Cruz y otros pueblos de Corrientes y Brasil [...]"(FERNÁNDEZ RAMOS, 1928 y CAMBAS, 1945, entre otros).

La ruta cartográfica del poblamiento de fines del siglo XIX y principios del XX, señalaba el avance de la movilidad social en sentido sur - norte; describiendo la reocupación de espacios más urbanizados hacia la ocupación de zonas rurales y selváticas. La disponibilidad de tierras, incorporadas a fin de transformarse en espacios productivos, la multiplicación de las actividades económicas y el abanico de posibilidades laborales, en el marco de la diversificación de la economía, eran factores que se combinaban y definían esta trayectoria expansiva. En ese contexto, la dinámica social en la frontera misionera -

\footnotetext{
${ }^{16}$ Actualmente localizada en la parte central de la Provincia de Misiones, entre las localidades de Oberá y Leandro N. Além.

${ }^{17}$ El gobierno correntino crea el departamento de Candelaria (1870), siendo Trinchera de San José (actual Posadas, 1879) la capital; mientras que el departamento de Santo Tomé adquiere nueva extensión que abarcaba hasta el Arroyo Aguapey.
} 
correntina ubicaba a las familias de correntinos a uno y otro lado del límite, componiendo la población de localidades emergentes que interactuaban con las ya existentes, y en esa intersección socio - espacial estaban vinculadas y/o reciclaban tramas de relaciones inter familiares, de sociabilidad y de asociación; articuladas por el parentesco, la amistad, la solidaridad y el compañerismo.

En esa franja fronteriza del sur misionero y norte correntino, localizamos familias Montiel, Ruiz, Navaja Centeno, Scotto, Lara, Escobar y Vedoya (TSCHUMI, 1948). Es así que, focalizamos la mirada en la frontera interna, en tanto espacio de interacción e intercambio social continuos, entre dos unidades político - administrativas dentro del Estado Argentino, el Territorio Nacional de Misiones (TNM) y la Provincia de Corrientes; donde estas familias se hallan interactuando entre sí mediante estrategias de alianzas matrimoniales y de parentesco, también, desde las relaciones interpersonales, de amistad, de trabajo, de paisanaje, de participación en ámbitos socio - culturales, etc. La trayectoria de cada una de ellas, describe una movilidad orientada desde las actividades económicas que desarrollan los sujetos, fundamentalmente varones, y define las localizaciones definitivas del grupo familiar. Entonces, en torno a las actividades impulsadas por la economía regional/local, extractiva agrícola y comercial, en los rubros predominantes, ganadero - yerbatero y de servicios, se desenvuelven las prácticas sociales de algunos sujetos representativos de este sector socio económico correntino; aprovechando de las posibilidades que, desde su situación de pobladores fronterizos, le otorga el usufructo, ambivalente, de oportunidades para la acumulación y participación en el circuito de los bienes económicos; posicionándose, incluso, en los ámbitos culturales y de la política en los espacios locales ya que la mayoría de las familias se radicaron definitivamente en territorio misionero.

Figura $\mathbf{N}^{\circ}$ 3: Comisionados Municipales de Posadas 1947 - 1951

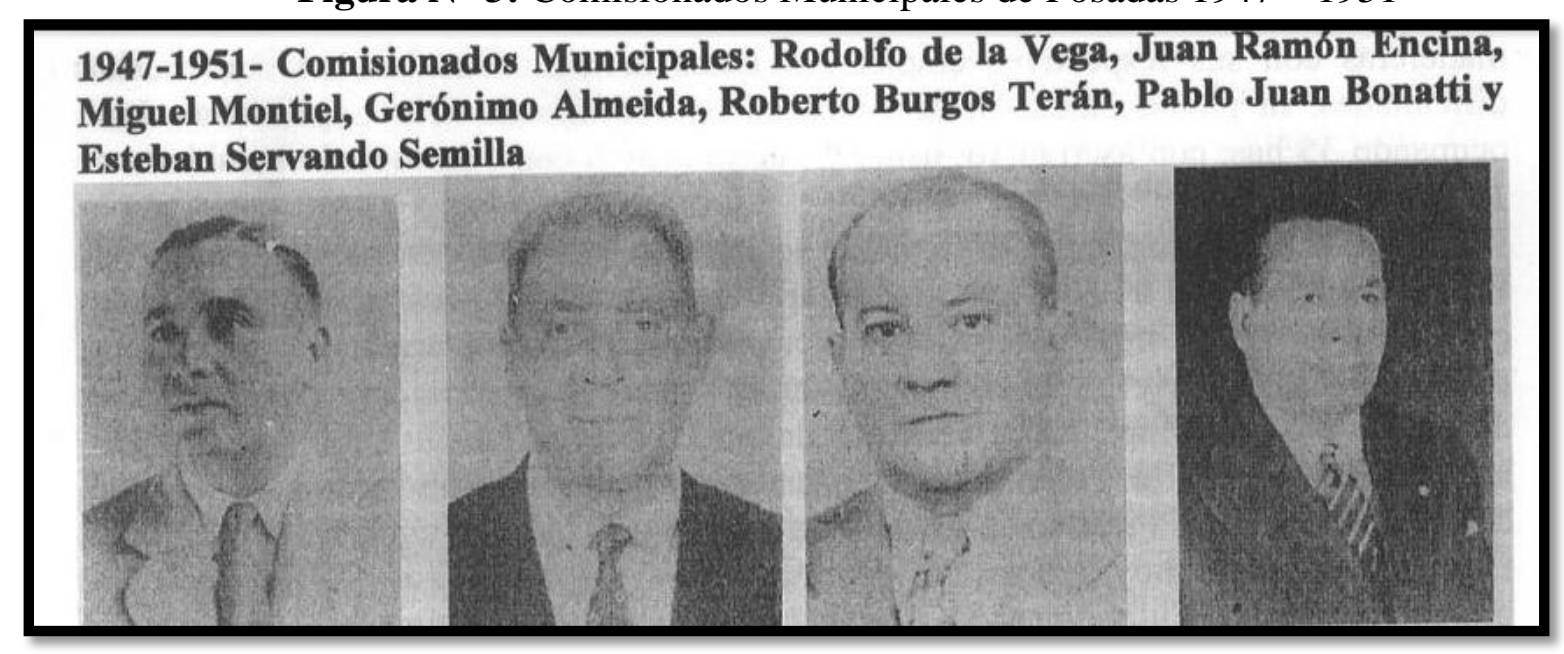

Fuente: Etorena de Freaza y Freaza (2010).

Miguel Montiel procede de Corrientes Capital desenvuelve sus actividades iniciales en la frontera misionera - correntina, hasta que se transforma en un trabajador independiente a cuenta propia en la ciudad de Posadas. La ruta laboral de este sujeto demuestra que las actividades desarrolladas como empleado, capataz y administrador de establecimientos ganaderos, le permitió una acumulación de experiencias en diversos ámbitos geográficos y la interacción con personas en múltiples espacios institucionales, conocimientos y trato con las entidades bancarias además del aprendizaje sobre procedimientos contables y sistemas de financiamiento que, combinado, a sus propias habilidades para los negocios lo transformo en un comerciante independiente, abastecedor - al por mayor y menor - de ganado en pie y comprador y vendedor de tierras y propiedades. De esta manera, incrementó su patrimonio 
familiar con múltiples bienes: vacunos, yerbales, casas y varias propiedades en Posadas y sus alrededores; además de un atractivo capital en dinero ya mediando el siglo XX.

\section{Gráfico $\mathbf{N}^{\circ}$ 1: Familia Montie}

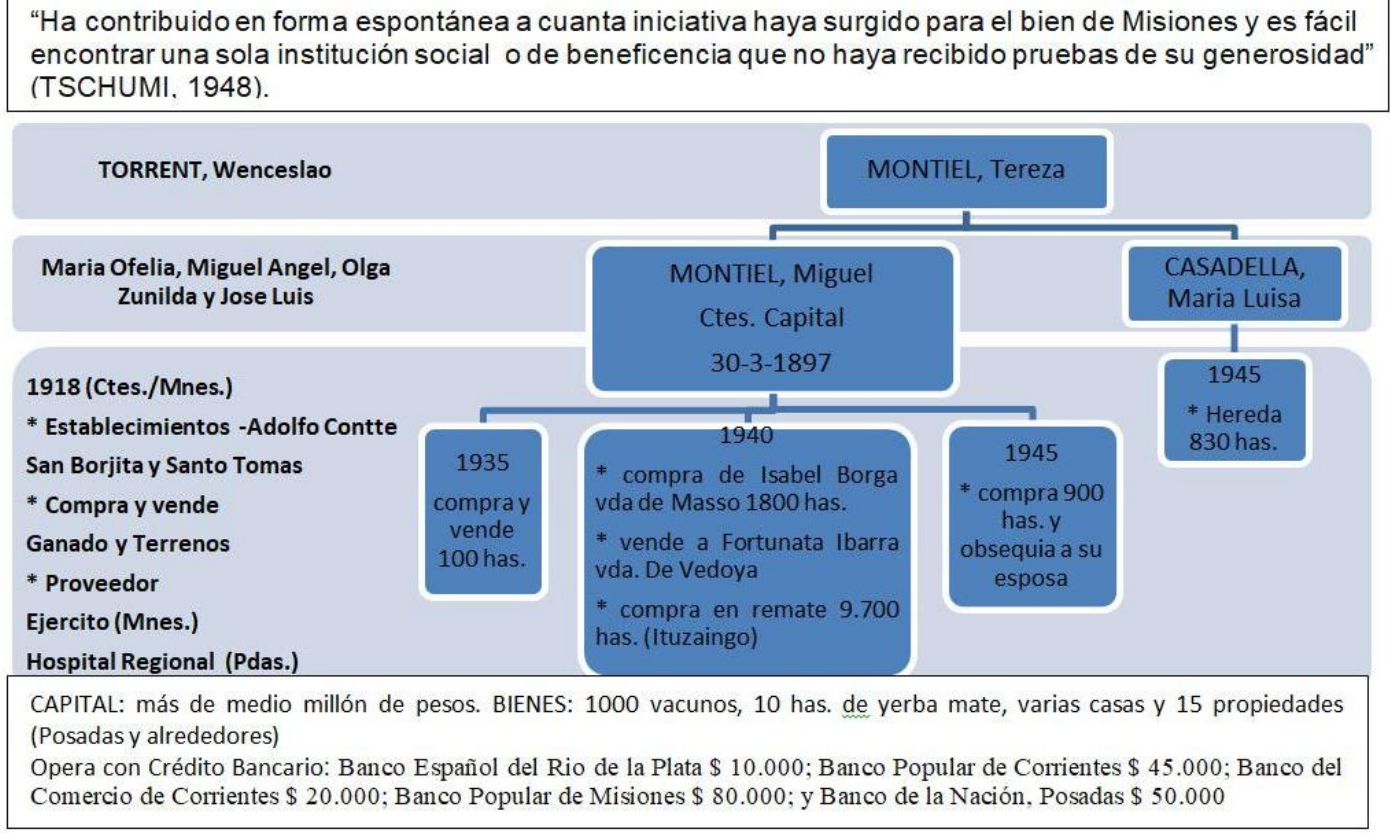

Fuente: Tschumi (1948). Elaboración propia.

Las estrategias para la conservación/mantención de los bienes económicos de estas familias residían en combinar capitales mediante el matrimonio, la delegación de herencias y la incorporación de nuevos integrantes al grupo familiar. Los jefes de familias poseedoras de tierras y bienes, como lo es la de Miguel Montiel, acostumbraban a desarrollar distintas estrategias para conservar lo adquirido y sumar beneficios a través de su descendencia, una de ellas era a través de la herencia; que les permitía posicionar a algunos hijos varones y/o conceder importantes y cuantiosas dotes a aquellas hijas mujeres cuyos esposos no eran adinerados ${ }^{18}$. Además, las familias tradicionales recibían con agrado a los comerciantes como yernos y los integraban mediante el matrimonio y/o las alianzas económicas, políticas y partidarias; de esta manera incorporaban a nuevos miembros habilitando cierta movilidad de los grupos familiares y, fundamentalmente, promovían la ampliación de la riqueza y del poder. Nuevos comerciantes emergieron de esa manera y en ese escenario, negociando no solo la producción propiamente misionera sino, también, de rubros distintivos de la economía correntina; pues la producción ganadera de los establecimientos ganaderos cercanos a la zona sur limítrofe a Corrientes, abastecía el consumo local de las nuevas ciudades y poblados.

Las instituciones políticas, culturales y, fundamentalmente, las educativas fueron las encargadas de fundar el imaginario social de la argentinidad al tiempo que argentinizaban e integraban a los sujetos de múltiples anclajes de identificación étnica/nacional y local de

\footnotetext{
${ }^{18}$ En relación a la herencia, desde la normativa jurídica se determinaba la potestad del hombre para administrar los bienes familiares - incluso los de la esposa, llevados al matrimonio como los adquiridos después por título propio -; sin embargo, desde el punto de vista de la sucesión, establecía que el cónyuge era el heredero forzoso, con los descendientes y ascendientes, $\mathrm{y}$, a falta de unos y otros, se consideraba sucesor universal, dándole como reserva la mitad del caudal hereditario (TORRADO, 2003).
} 
referencia/pertenencia. Esos espacios institucionales abrieron la posibilidad de afincamiento de maestras y maestros correntinos conformando el plantel docente de las escuelas en diversas localidades misioneras; es así que desde 1880/90, un collar de escuelas se estableció en la zona sur misionera trazando una ruta entre Corpus y San Javier y, progresivamente, otros establecimientos avanzarían hacia la zona norte del espacio misionero. Existe mucha documentación respecto de la implosión y el impacto causado por la presencia de esta comunidad escolar, mientras que la información respecto de los actores de la salud es más acotada $\mathrm{y}$, tal vez menos impactante; sin embargo la importancia de la problemática salud/enfermedad es crucial en los TN y determina la aparición paulatina de instituciones específicas a falta de fondos y especialistas.

Otros correntinos ingresaron ya siendo profesionales, jóvenes solteros o parejas de maestros y médicos por ejemplo, interesados en realizarse y formar sus propios bienes económicos; estos constituyeron el núcleo intelectual de las sociedades locales y, generalmente, ocupaban cargos de funcionarios públicos, directivos de escuelas, representantes de la salud, integrantes de los concejos municipales, espacios políticos, etc. de los que la población en general y el mismo Tschumi se referían destacando el "trato cordial", la "simpatía" y el sentido "humano" de los mismos; lo que les valía, en muchos casos, la calificación de "padre de los pobres". Desde ese lugar, recuperamos la trayectoria del médico Pablo Ruiz, citada por Tschumi y señalada en las publicidades de los anuarios de 1923 y 1943, pues contiene un recorrido interesante como profesional en el ámbito de la salud a nivel local: fundador y organizador del Internado para Dementes y del Asilo de Ancianos y de representante de las instituciones sanitarias que vinculan a los pueblos: Jefe de Sanidad del TNM, Santo Tomé y Virasoro radicado en Posadas. Estos datos aluden a las necesidades urgentes en materia sanitaria, la falta de ellos describen esta circularidad y acumulación de cargos, al menos pensada desde este sujeto en particular.

Figura $\mathbf{N}^{\circ}$ 4: Publicidad sobre médico local

\begin{tabular}{|c|}
\hline Dr. P. OSVALDO RUIZ \\
Médico Cirujano \\
Médico del Mutualismo Antituberculoso del Magisterio \\
Atiende partos y Clínicas \\
Consultas: De 8 a 10 y 15 a 17
\end{tabular}

Fuente: Sosa, Atanasio. Guía General de Misiones. Posadas, 1923 y Bordón, Arturo y Valdovinos Elías. Guía General de Misiones. Descripción geográfica, Histórica, Política, Económica, Cultural y Social de Misiones. Posadas, Ed. América, 1943.

A partir de otras trayectorias observamos, en el transcurso de las décadas del '20 y del '30, ocurre un aumento de las actividades comerciales tanto en el ámbito rural, en torno a los rubros ganadero (ganado y campos) y agrícola (chacras y yerbales), como en el ámbito urbano, alrededor de la compra/venta de propiedades y renta de lugares de depósito/acopio en la ciudad capitalina y en otras localidades del interior del TNM y del país. Así, lo demuestra la ruta de la Familia Scotto, procedente de Garruchos y asentada en Misiones, que habiendo amasado un capital importante deciden, a fines del '40, que la familia base migre a Buenos Aires, para dedicarse al negocio de importación de productos. Mediante la trayectoria de esta familia reconocemos la participación del comerciante, como un sujeto que sosteniendo esa actividad con honradez y constancia, tiene la posibilidad de edificar, rápidamente, un 
patrimonio económico y modificar la situación de pobreza; puesto que Rogelio (padre) llego al TNM "con dinero prestado e instalo tienda y almacén" y, al momento de retirarse a la capital del país, dejo el principal y más surtido negocio en Apóstoles, asegurando el futuro de sus hijos.

El comercio era una actividad relevante y ya ejercitada históricamente en este territorio fronterizo, los productos de la actividad extractiva - yerbatera y maderera - a los que ahora se agregaban los rubros de la producción agrícola circulaban tanto en los mercados de la región como en los mercados nacionales de los Estados limítrofes. En ese contexto, radicados en Apóstoles, participan las familias de Tomás Lara y de Alarico Escobar, ambos provenientes de Santo Tomé; el primero dedicado al acopio de cítricos, luego empleado en el establecimiento de la familia Scotto y, por último, consagrado al servicio de transporte y; el segundo, un profesional escribano que se inmiscuyo participando fuertemente en las instituciones culturales.

Figura $\mathbf{N}^{\circ}$ 5: Publicidad sobre escribano nacional

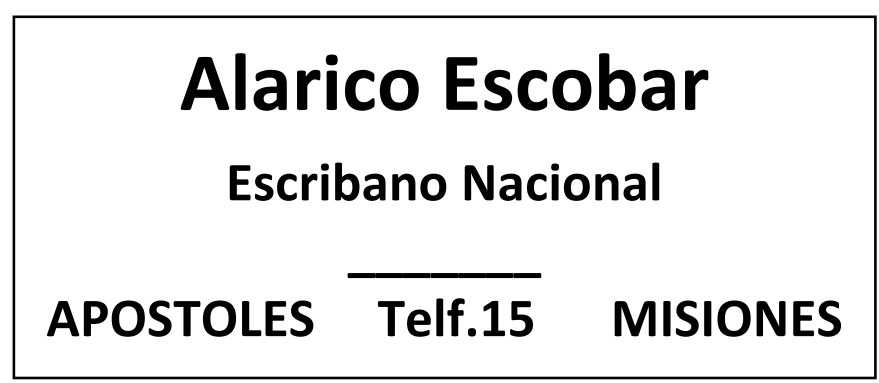

Fuente: Libro Azul de Misiones 1935/36. Guía del Territorio Nacional(S/D).

Alarico pertenece a una clase social adinerada, a juzgar por la posibilidad de formarse en un centro de excelencia a nivel nacional y debido a la acumulación de capital en propiedades, consiguió construir una fortuna ejerciendo su profesión y dedicándose a la producción yerbatera. La fuente subraya que "preciso del Concejo Municipal" en dos ocasiones, expresión significativa ya que fue un poblador que, por su condición de intelectual y de propietario, tuvo peso social en el pueblo. En cambio, Tomás Lara se desenvolvió en múltiples actividades asociadas al comercio, acopiador, empleado/administrador y transportista; sobre este sujeto no se consigna asentamiento definitivo puesto que su particular actividad de transportista impone una trayectoria que transcurre en diferentes puntos del TNM.

Las familias que fuimos examinando corresponden a las que se establecieron en territorio misionero, donde compraban tierras/chacras/propiedades/animales y se dedicaban a la producción de yerba, al negocio inmobiliario, al comercio en almacenes generales, al servicio de transporte y a la venta de ganado; combinando, en varias ocasiones, dos o más de esos rubros; salvo excepciones que solo ejercieron funciones de profesionales. Las otras familias, tenían bienes económicos en el TNM, fundamentalmente tierras, pero residían en localidades de Corrientes, es el caso de la familia Navaja Centeno en Virasoro y otras, como la familia Vedoya, conservaban sus establecimientos ganaderos a una y otra banda del límite; entre Misiones y Corrientes. 


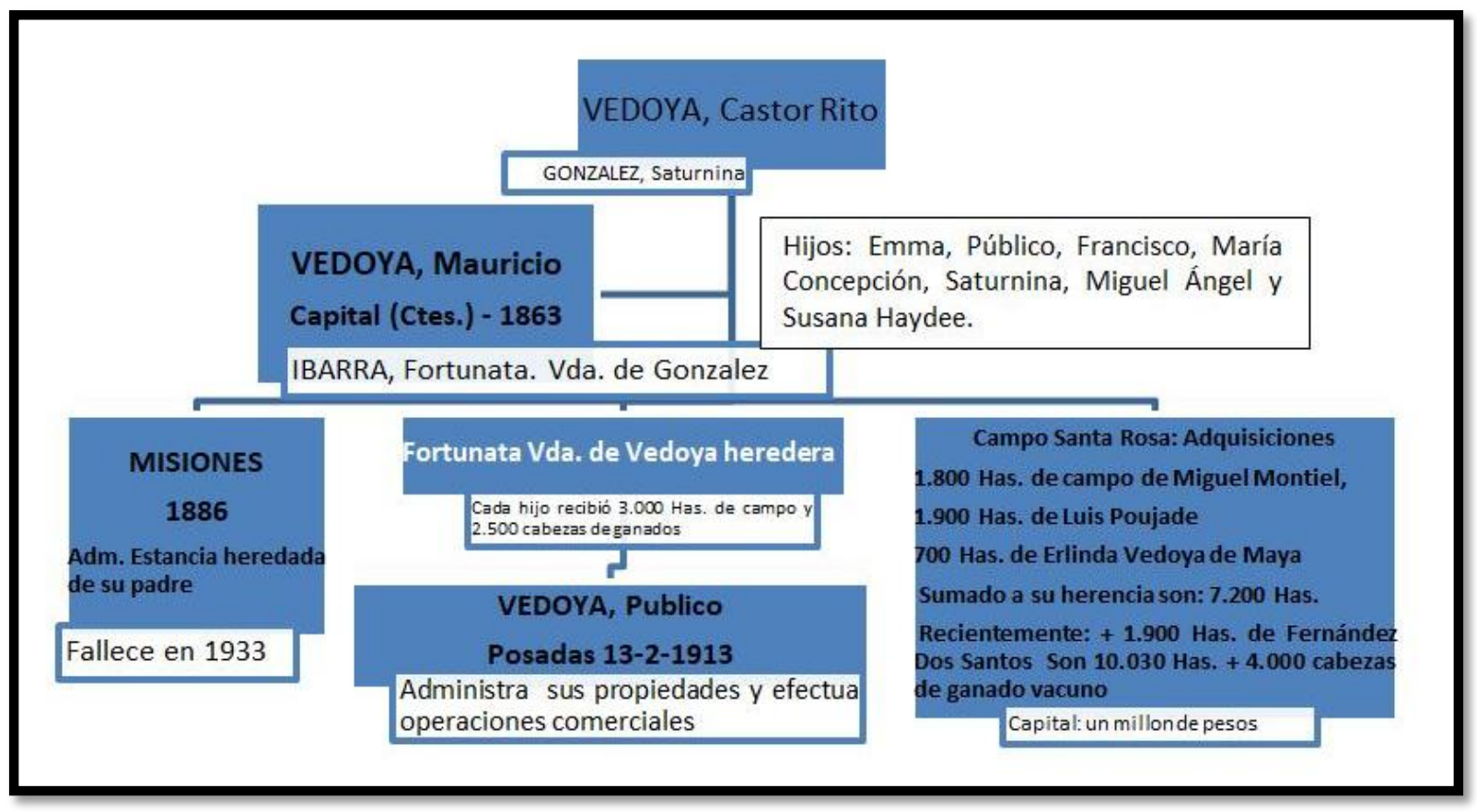

Fuente: Tschumi (1948). Elaboración propia.

En términos conclusivos, respecto de quiénes son, qué hacían y cómo se vinculaban las familias de criollos, familias correntinas, entendemos que desde el análisis de "...las trayectorias familiares [pudimos] visualizar un espacio social, económico y político por el cual [estos] individuos transitaron/construyeron, excediendo y tensionando los límites jurisdiccionales o políticos" (QUIÑONES, 2009, p. 2) interprovinciales. Y situadas en un contexto fronterizo establecieron vínculos de innegable fortaleza, pues frente al ingreso e incorporación de los inmigrantes, se sostuvieron como grupo redoblando esfuerzos y reactualizando estrategias sociales que les permitieron agenciarse un reposicionamiento y ascenso social dentro de la sociedad misionera; acumulando riquezas, sea material obtenida por sus actividades económicas, como simbólica utilizando el capital social adquirido/acumulado en las redes sociales por las que circularon.

La inmigración europea y asiática, se incluyó en la región de frontera, constituyendo esta composición social previa integrada por indios, negros y criollos, y este hecho provoco el aumento poblacional desmedido e incremento la movilidad social en los lindes de los Estados Nacionales como al interior de los mismos; complejizando, aún más, la heterogeneidad social de la sociedad territoriana. La dinámica de la movilidad social, en esta región de frontera, es detonada por un impulso exógeno, promovido por las situaciones económicas/militares existentes en los países del viejo continente, como endógeno, fomentado por las políticas migratorias implementadas en los países fronterizos de Argentina, Paraguay y Brasil y, simultáneamente, determinado por las oportunidades de acceso a los recursos que la situación de fronterizos les propiciaba tanto a migrantes (establecidos) como a inmigrantes (outsiders).

La muestra relevada por Tschumi (1948) pone en evidencia esa variedad en las movilidades de las familias migrantes, provenientes de las provincias argentinas, de los estados fronterizos y al interior de Misiones, constituidas por inmigrantes y descendientes de inmigrantes y de las familias de inmigrantes que ingresan directamente después de recalar en Buenos Aires, en ambos casos, tanto los ingresos como los asentamientos refieren a diversas oleadas de movilidad. En ese proceso de incorporación, la sociedad territoriana recibe a las 
familias procedentes de las provincias de Buenos Aires, Santa Fe, Mendoza, Corrientes y Santa Cruz como, así también, denuncia cierto grado de movilidad de las familias que hace tiempo habían ingresado y poblaban Misiones (Gráfico 3).

Gráfico N 3: Población Argentina en el Territorio Nacional de Misiones

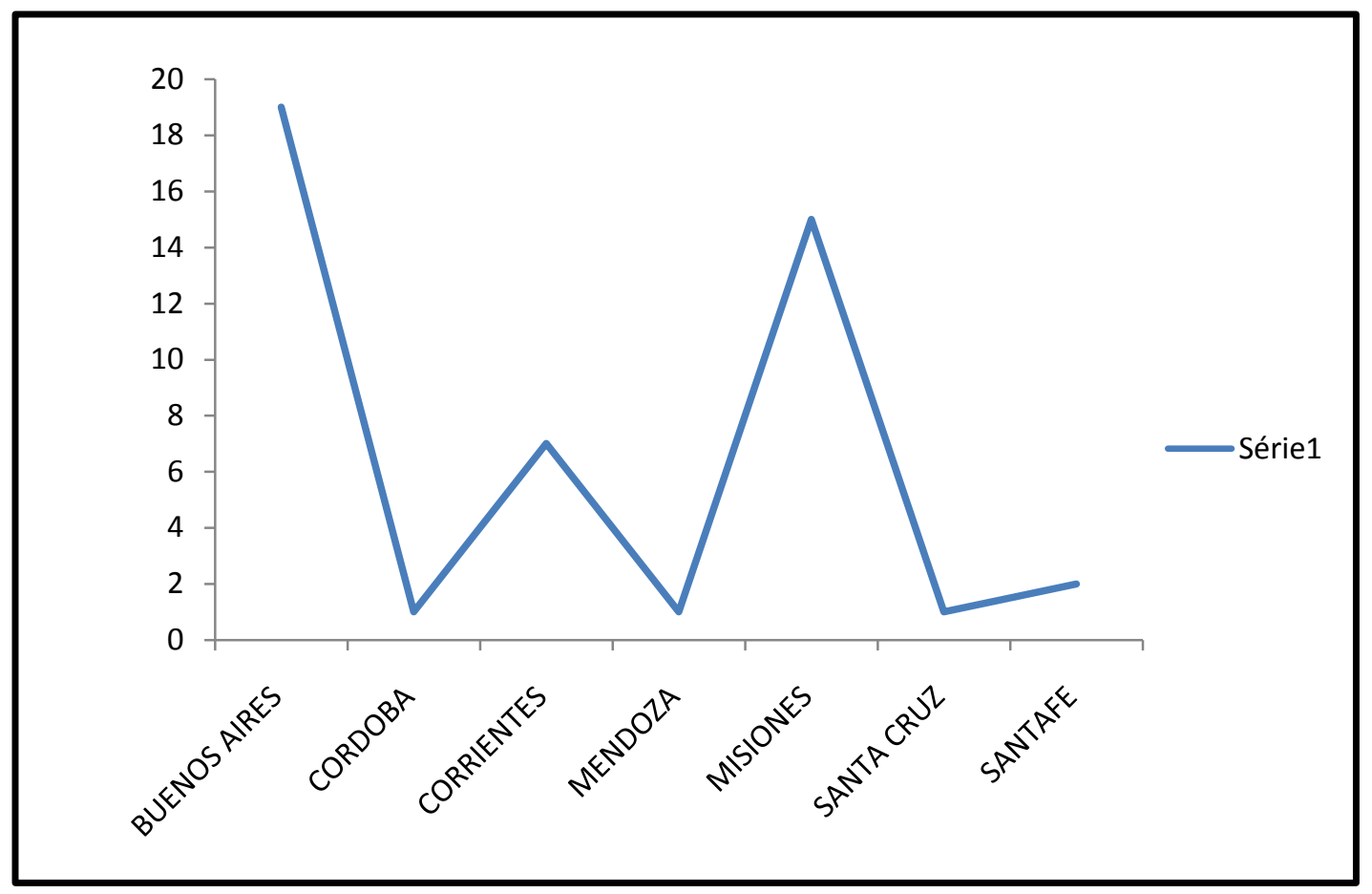

Fuente: Tschumi (1948). Pobladores: Buenos Aires (19), Córdoba (1),

Corrientes (7), Mendoza (1), Misiones (15), Santa Cruz (1) y Santa Fe (2). Elaboración propia.

De este conjunto de familias, hijos de inmigrantes nacidos en territorio argentino, algunos de sus integrantes, especialmente bonaerenses, se han desplazado tanto dentro del país como hacia estados europeos, Alemania, Suiza Italia, etc., a fin de formarse profesionalmente como agrónomos, naturalistas, médicos, profesores y agrimensores y, como tales, regresaron al país para establecerse definitivamente en Misiones, Caraguatay, Oro Verde, Campo Ramón, Posadas, Montecarlo, Santo Pipo y Eldorado en el transcurso de las décadas del '20, '30 y '40; donde varios de ellos se posicionaron ocupando diversos cargos en instituciones político- culturales: Comisión de Fomento, Cooperativas, etc. La motivación que los atrajo es muy variada, aunque al disponer de tierras, mayoritariamente se inclinaron por la producción de yerba mate; a la que agregaron, luego, la producción de cítricos, tung, arroz y otros cultivos según los ciclos y la diversificación de la economía local. Otros orientaron sus actividades hacia los rubros del comercio y los servicios, por ejemplo, el establecimiento de empresas de transporte y de cría de animales exóticos y de raza, actividades complementadas a espacios de socialización, diversión y entretenimiento pues desarrollaban la práctica de la caza y la pesca y, para ello, algunos construyeron mansiones o hermosas casas destinadas a estancias de placer donde no siempre residían o lo hacían temporariamente (Gráfico 4). 
Gráfico $N^{\circ}$ 4: Familia Aguiar

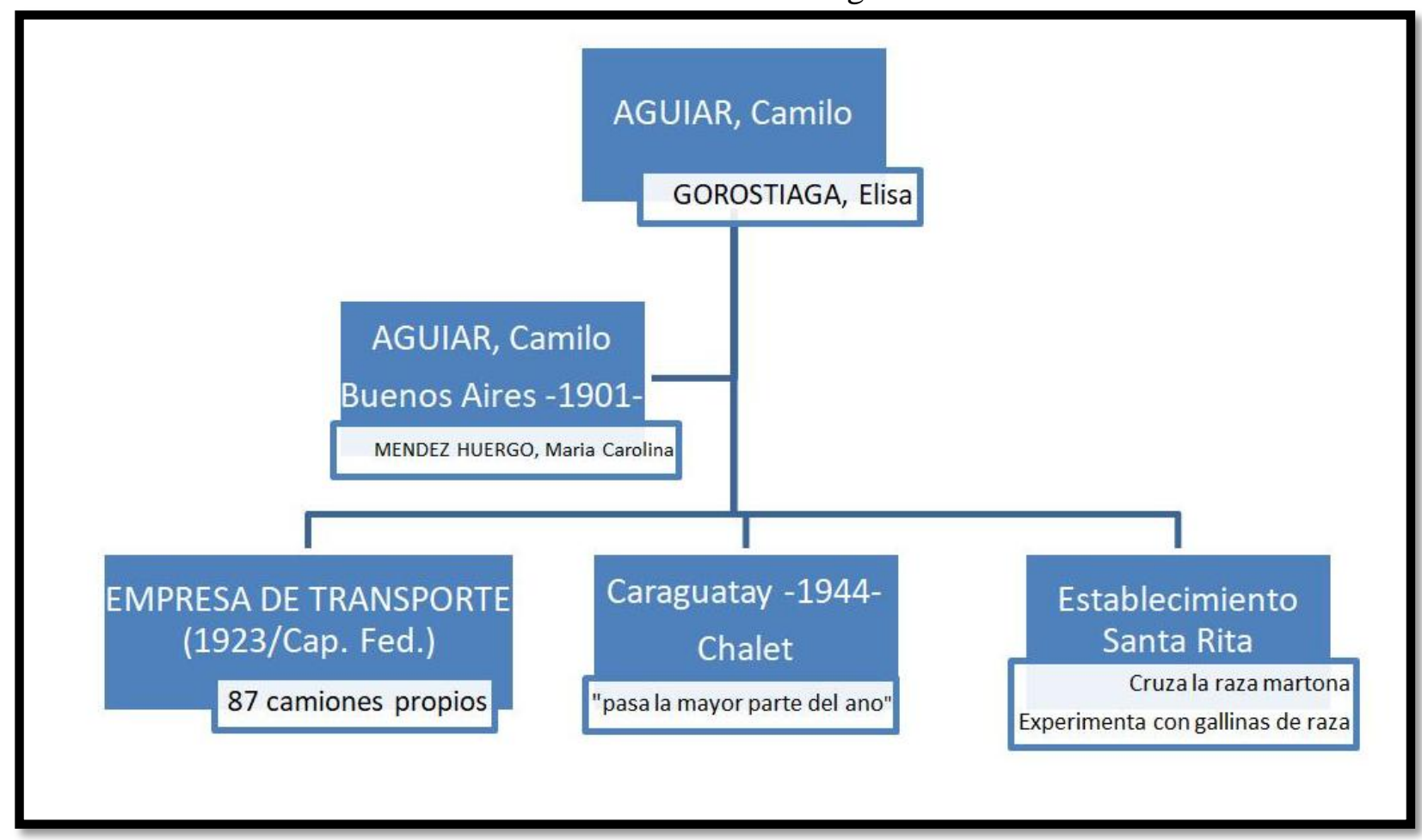

Fuente: Tschumi (1948). Elaboración propia.

Entre las familias que provenían de la provincia santafesina Tschumi, se registra a una mujer como integrante central del grupo familiar, excepción que contrasta con la totalidad de las biografías dispuesta desde la centralidad del componente masculino. Cresy Therler de Krumkamp vino con su esposo (1921) a Puerto Rico, donde compraron tierras y se dedicaron a plantar yerba y otros cultivos e instalaron un hotel (1929); luego denominado Hotel Suizo, "que era el más lujoso y único con pileta de natación". Lo interesante de esta trayectoria es que ella, al enviudar, se ocupa de los negocios del esposo y, además, de los de su yerno.

Figura $\mathbf{N}^{\circ}$ 6: Publicidad Krumkamp

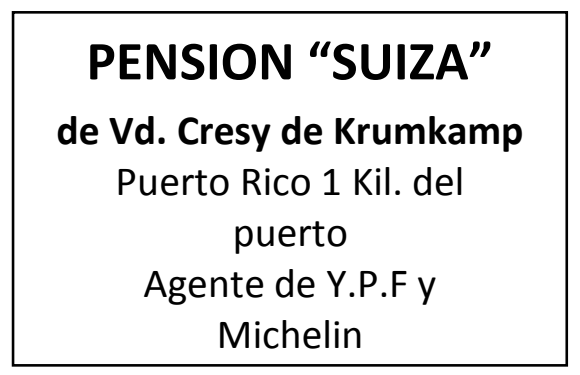

Fuente: HASSEL, Hermann. Misiones, almanaque-guía para el año 1938. Posadas-

Misiones, Imprenta Foto Moderna, 1938.

Tomamos como excusa este dato para analizar acerca de cómo el autor compone los espacios de participación femenina. En general, la intervención de la gran mayoría de las mujeres, presuponiendo de algunas alusiones circunstanciales, indicaban el desenvolvimiento de funciones asignadas junto a los hombres: la construcción de la vivienda y los quehaceres 
de la chacra; además de lo socialmente establecido como roles femeninos: la tarea en el hogar, la atención y cuidado de los niños y el esposo. Sin embargo, anota destacadamente la labor de varias de ellas, como administradoras de los bienes patrimoniales, por sucesión/herencia. Esta era una situación de privilegio que solo usufructuaban las hijas y/o esposas de familias adineradas, sean criollas o inmigrantes, puesto que tanto la vda. de Krumkamp (hija de inmigrante) como Fortunata Ibarra vda. de González y la vda. de Vedoya (esposas criollas) "administraron sus propiedades" y se ocuparon de "las operaciones comerciales" o como Cristina vda. de Byling (esposa de un dinamarqués) "ha demostrado grandes dotes de administradora".

Además, Tschumi refiere que la esposa de un sueco "escribe frecuentemente para las revistas suecas y dinamarquesas sobre las bellezas de Misiones y es activa propulsora de las actividades artísticas y culturales del territorio" y, a través de ella, ubica a las mujeres participando en espacios de producción intelectual/literaria; este caso refiere a la producción domiciliaria destinada a revistas del exterior, sin embargo, las revistas locales registran, también, autorías literarias femeninas en publicaciones locales que referían sobre temáticas delimitadas: en torno a la educación, la familia, la producción poética, etc. (Medina, 2019). Ese territorio ocupado por las mujeres escritoras/productoras, en minoría numérica frente al sector masculino, es equiparable a la participación de ellas en el campo educativo; donde reducidas al espacio áulico secundaban al sector masculino y, a pesar de ser una mayoría numérica frente a los maestros hombres, muy pocas ocupaban cargos o cumplían funciones directivas (MEDINA, 2017 y 2018). Tales protagonismos, recopilados indiciaria y/o fragmentariamente; dan cuenta de la actuación de las mujeres, diferenciándolas en ámbitos y sectores sociales particularizados: insertas en familias rurales de clase media instaladas en los pueblos e integrando familias urbanas y/o rurales de clase media alta o de la élite, localizadas en las ciudades centro o en localidades ganaderas.

El censo de población de 1947, ponía en evidencia no solo el gran crecimiento demográfico del TNM sino, además, al clasificar a la población por sexos, evidenciaba una mínima diferencia numérica entre varones y mujeres.

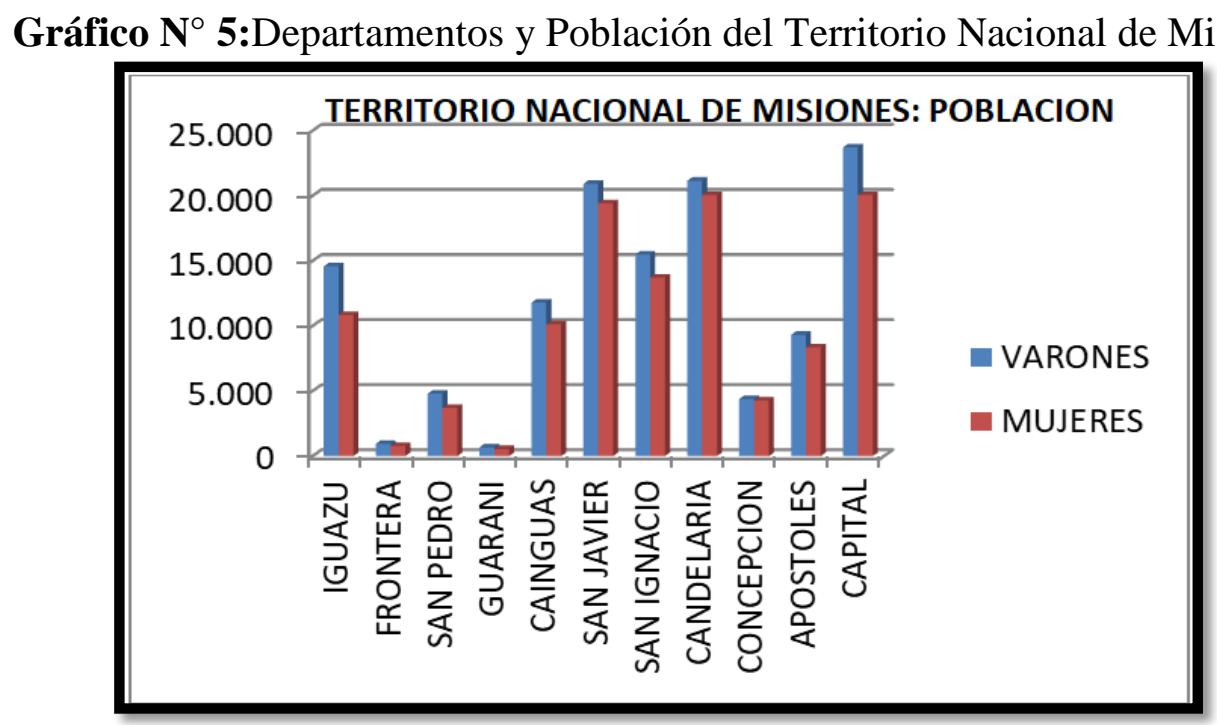

Fuente: Plan Quinquenal (1950). Elaboración propia

Es importante subrayar este dato debido a la razón por la cual el Estado requiere de información sobre la población en general y sobre la contabilización puntualizada del grupo femenino; pues en ese entonces las mujeres adquirían la condición de ciudadanas considerándolas como sujetos de derecho y con ello se pasarían a ser, además de madres y 
esposas, electoras, militantes y candidatas en espacios partidarios (OVIEDO, 2019 en OVIEDO y COSSI-COMP, 2019). Ya para entonces, las mujeres habían ampliado los espacios de participación fuera del hogar, desafiando los obstáculos y tensiones por ocupar lugares considerados socialmente como masculinos no solo por el sector varonil, que se percibía desplazado, sino también por el conjunto de mujeres que hasta ahora adhería a la concepción de un modelo tradicional y patriarcal de organización de la familia; en el que el rol de las mujeres continuaba supeditado solamente a ese espacio familiar. Es decir que, si bien, un grupo de mujeres acapararon nuevos espacios de participación, logrados mediante la formación profesional e intelectual, la inserción laboral y la militancia en espacios partidarios; en relación a las valoraciones sociales, continuaban percibiéndolas según el viejo esquema epocal y ellas proseguían siendo el blanco de la censura y la sanción en mirada desde la mirada social.

El poblamiento y asentamiento de las familias de la inmigración europea en Misiones se encuadro, fundamentalmente, en la colonización proyectada por el Estado y, en menor medida, por las empresas colonizadoras que direccionaban sus pasos, país de salida y país de destino y asentamiento en diversos lugares/tierras previstas. El proyecto colonizador estatal comenzó a funcionar en 1876, mientras que el proyecto colonizador privado toma impulso en 1919, el primero planifica la ocupación de las tierras en todo el territorio misionero, Candelaria, Cerro Corá, San Javier, Bompland, entre otros, mientras que el segundo lo puntualiza en territorios localizados, como Eldorado, Puerto Rico, y Montecarlo, etc. de la mano de empresarios como Schwelm y Culmey.

Veamos, brevemente, las características de la colonización de la colonia de Eldorado fue administrada por la "Compañía Colonizadora Eldorado, Explotación de Bosques Ltda." presidida por Adolfo Schwelm. La misma fue exitosa en el sentido de determinar el asentamiento de inmigrantes germánicos, tanto que desde los estudios sobre la colonización se afirma que los orígenes de la organización de esos espacios son resultado de los proyectos personales de los empresarios colonizadores; respondiendo al lema "poblar y producir" establecido como política de estado (ARENHARDT, 2003, 2005).

Tabla $\mathbf{N}^{\circ}$ 1: Inmigrantes establecidos en Eldorado.

\begin{tabular}{|l|}
\hline ELDORADO \\
\hline ALEMANIA \\
\hline AUSTRALIA \\
\hline AUSTRIA \\
\hline BRASIL \\
\hline BUENOS AIRES \\
\hline COLONIA \\
\hline DINAMARCA \\
\hline ESPANA \\
\hline HUNGRIA \\
ITALIA \\
\hline NEOZELANDIA \\
\hline PARAGUAY \\
\hline POLONIA \\
\hline POSADAS \\
\hline SANTA FE \\
\hline SUECIA \\
\hline SUIZA \\
\hline YUGOSLAVIA \\
\hline
\end{tabular}

Fuente: Tschumi (1948). Elaboración propia.

Esta apreciación es válida en tanto se refiere a que la mayoría de los pobladores asentados allí eran alemanes, por ende en esa localidad primo un modelo de organización y distribución de la ocupación territorial impuesta desde la Compañía que la fundara y los sujetos que integraron la sociedad local. Sin embargo, al examinar la composición social de 
población de Eldorado reconocemos que es uno de los lugares, al igual que Yerbal Viejo actual Oberá - de colonización estatal, donde existe una mayor multiplicidad de comunidades de inmigrantes (Tabla $\mathrm{N}^{\circ} 1$ ); según el registro de Tschumi como de la información existente en producciones locales sobre la historia de esos pueblos.

En relación a Eldorado "[...], la demanda de tierra familiar provino en gran medida de agricultores de origen alemán instalados en Brasil, los que oficiaron de "maestros" para los inmigrantes llegados de Europa que no tenían conocimientos del trabajo en la "chacra" (SCHIAVONI y GALLERO, 2017). Esta afirmación pone en evidencia la constante movilidad social en esta región de frontera, dentro y fuera de los países que la integran, movilizando a todos los componentes sociales, sean nativos o foráneos, a transitarla.

Entendemos que el proceso colonizador, es producto y resultado de la acción/gestión tanto estatal como privada, la cual delinea los territorios y las territorialidades diferenciadas, según origen de sus pobladores y composición social, formas de organización y distribución territorial etc. Sin embargo ambas formas de colonización estaban atravesadas por la colonización o poblamiento espontáneo; promovida por las acciones de los sujetos/habitantes de y en la región de frontera, que se apropiaron del territorio y tanto establecidos (aborígenes, negros y criollos) como outsiders (inmigrantes) describieron sus trayectorias, individuales y familiares, vivenciando, percibiendo y concibiéndolo como un territorio que les ofrecía múltiples posibilidades.

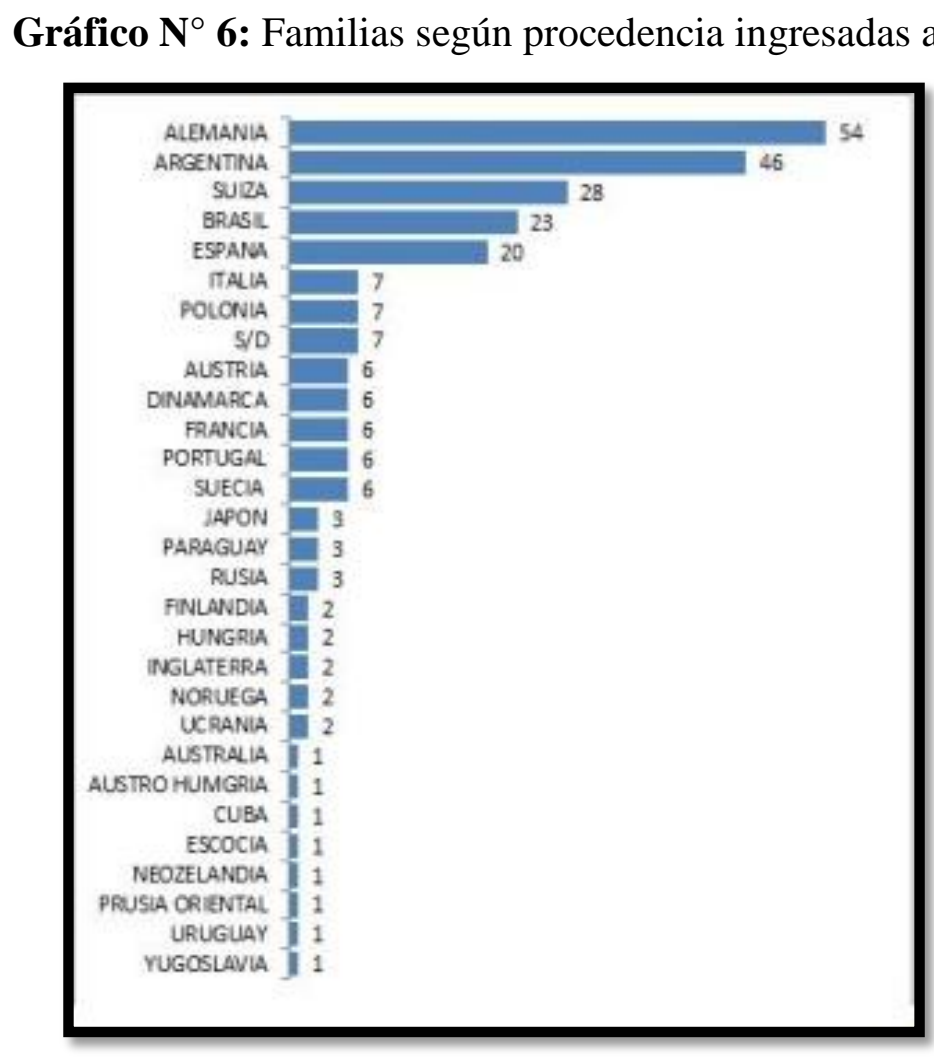

Fuente: Tschumi (1948). Elaboración propia.

Si bien, los inmigrantes fueron responsables de la decisión tanto de migrar como de la elección de destino, las situaciones socio- económicas particulares, el desconocimiento y el desarraigo, etc. modificaban sus planes y, aunque proyectaban y fijaban, con anticipación y cierta precisión, sus rumbos hacia los países a los que se incorporarían; una parte de ellos redirigía sus pasos al llegar al punto de destino y, unos, circulaban por varios lugares dentro 
del país de destino hasta establecerse definitivamente y, otros lo hacían entre los países contiguos al país de destino, después de pasar un tiempo probando suerte para cambiar su situación económica.

Al analizar el cuadro general de inmigrantes (alemanes, españoles, suizos, portugueses entre otros) e hijos de inmigrantes (argentinos y brasileños) que poblaban Misiones a mitad del siglo XX, según la muestra relevada por Tschumi, observamos que estadísticamente existe una mayoría alemanes, suizos y españoles -representativa de los inmigrantes- y una mayoría de argentinos y brasileños -representativa de los hijos de inmigrantes-; es decir que el acceso de población germana y de población brasileña son numéricamente importantes, la primera explica la razón del porqué se constituyen en una mayoría en Eldorado, ya que su concentración fue decidida arbitrariamente, y la segunda es indicativa del alto grado de movilidad de los pobladores de otras provincias hacia los TN donde existían tierras disponibles. Esta última premisa da cuenta también de la gran afluencia de la población brasileña cuya presencia, si bien se distribuida en gran parte del territorio misionera, fue más notable en la zona costera al río Uruguay.

Continuando la lectura, en relación a las edades de ingreso tanto de inmigrantes como de migrantes jefes de familias, según datos que aporta la fuente, reconocemos las siguientes franjas etarias desde las que observamos una baja proporción de pobladores ingresantes a la edad de 1 a 17 años de edad y de pobladores ingresantes entre 37 y 65 años de edad frente a una alta proporción de pobladores ingresantes que tenían entre 18 y 36 años de edad. Son significativas estas cifras a la hora de relacionar, dichas franjas etarias de ingresantes con los propósitos que el proyecto colonizador, el cual apostaba a la inserción de mano de obra calificada para el trabajo agrícola lo que, en parte, explica la afluencia mayoritaria de pobladores de grupos situados en una edad propicia y/o capacitada para el desempeño de tales actividades - entre 18 y 36 años - .

Gráfico $\mathbf{N}^{\circ}$ 7: Jefes de familias por Edades de ingreso al TNM

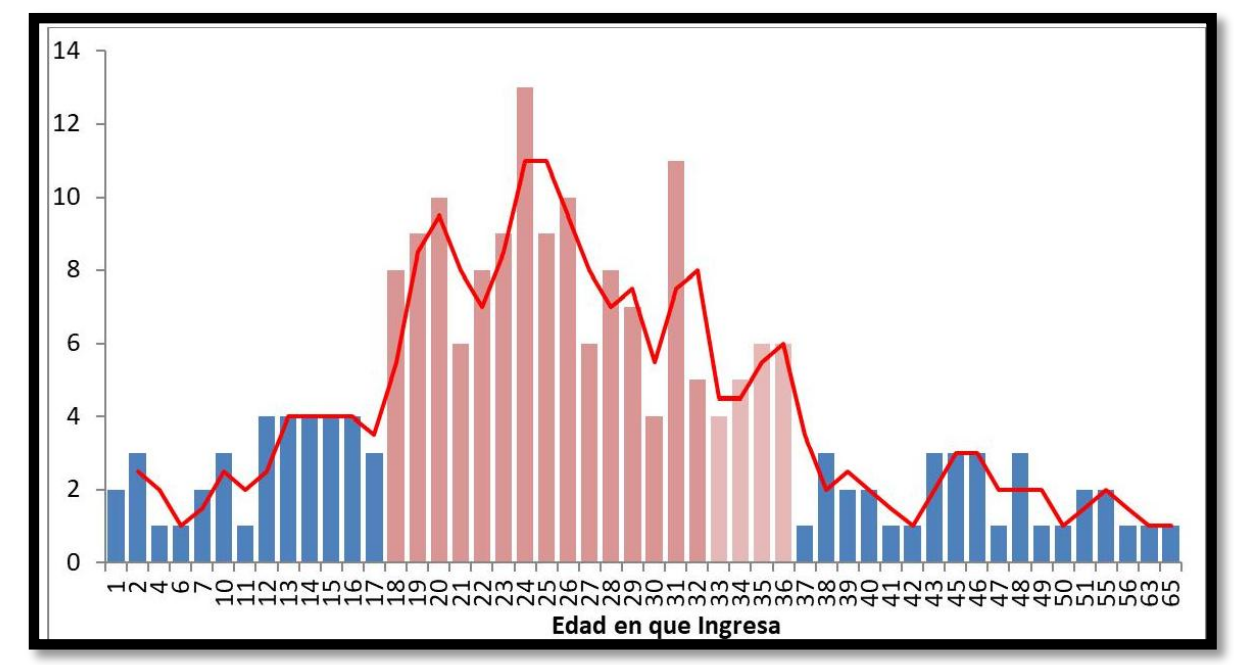

Fuente: Tschumi (1948). Elaboración propia.

No obstante, respecto de las otras franjas etarias de ingresantes, situados en la etapa infantil - adolescente, y la de adultos, situados en la etapa adultos en tránsito a la vejez - en minoría se explicarían, una a sabiendas de que los sujetos se mueven en grupos - familias, parientes, amigos, compañeros, etc. - por ende los niños, necesariamente, acompañan a sus padres y la otra, por lo general, responden a casos de conjuntos de pobladores asociados voluntariamente a fin de capitalizar recursos y afrontar inversiones de emprendimiento empresarial. 
El registro de Tschumi se compone de biografías breves elaboradas desde una mirada que ubica al grupo familiar a partir de un contexto de trayectorias particularizadas, perteneciente a sujetos destacados como jefes de familia, los que son seleccionados por su contribución al progreso y crecimiento de Misiones. Por ello, las anotaciones referencian además de sus datos personales, lugar y fecha de nacimiento, origen y estado civil y cantidad de hijos y progenitores, sus actividades y participación en las diversas organizaciones e instituciones económicas y culturales; mientras que la información sobre de los otros integrantes de la familia está acotada a la sola citación de los nombres de los hijos como de las esposas.

Es decir que la organización del relato sobre tales grupos o configuraciones familiares, se corresponde con un ordenamiento jerárquico de los integrantes que los conforman, implicadas en relaciones de poder dispuestas en una estructura vertical de distribución de poder: hombre-mujer-hijos. Desde esa perspectiva, se historizan las trayectorias de los llamados "Forjadores de Misiones" durante el período de colonización, cuyas rutas particulares y las tramas de relaciones que resultan del entrecruzamiento de ellas nos permiten avizorar, aproximativamente, sus comportamientos y prácticas en torno a las formas de vinculación social.

En cuanto a las alianzas matrimoniales, distinguimos comportamientos diferenciados, Tschumi establece el estado civil de los pobladores en las categorías de "soltero" (ingresa en esa situación), "casado" (contrajo matrimonio en el país de origen) y "se casó" (contrajo nupcias en el país de destino), obtenidos al cruzar tales datos con la de nacionalidad u origen cuyos resultados manifiestan, en líneas generales, la tendencia refleja una superioridad respecto de los que ingresan ya casados y, en líneas particularizadas, una mayor vocación matrimonial entre los alemanes y los suizos. Estos, a su vez, son los que tienen las cifras más alta respecto de los que ingresan en calidad tanto de solteros como de matrimoniados, no obstante en las comunidades de españoles y de brasileños se evidencia la tendencia es contraer nupcias una vez establecidos en Misiones. Es de suponer que la orientación generalizada de los brasileños a contraer matrimonio de radicación, se entiende al considerar la existencia de lazos interpersonales cercanos y constitutivos de las relaciones habituales/cotidianas que caracterizan a los habitantes de la región de frontera.

Tabla $\mathbf{N}^{\circ}$ 2: Situación Civil por nacionalidad en el TNM.

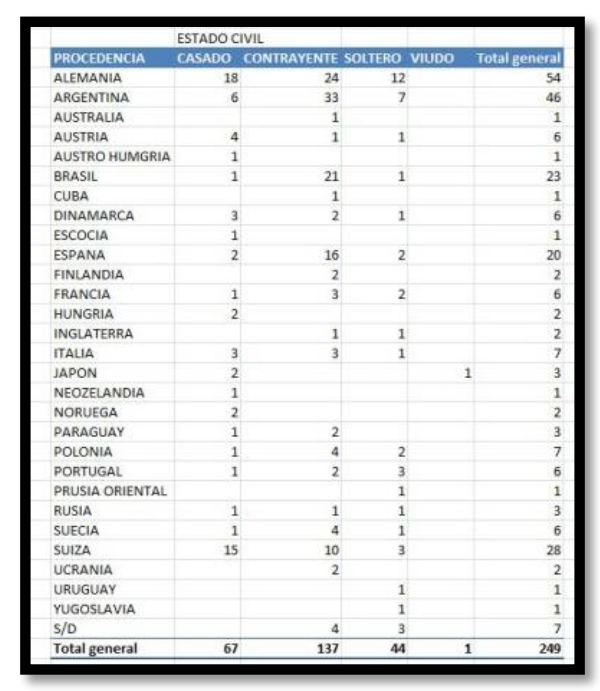

Fuente: Tschumi (1948). Elaboración propia. 
En la tabla $\mathrm{N}^{\circ} 3$ visualizamos que la mayoría de las familias tenían entre dos y cuatro hijos, un grupo intermedio tenía entre seis y ocho hijos y una minoría de ellas tenía entre nueve y doce hijos. Es decir que, a juzgar por estos datos parciales, las familias hoy llamadas numerosas eran las menos habituales, existe solo un caso excepcional de grupo familiar constituido por padre, madre y 27 hijos, se trata de hijos adoptivos; hecho llamativo e interesante de ser examinado específicamente como problemática de investigación. Estos datos nos plantean nuevos interrogantes sobre las familias o las configuraciones familiares al observar, por un lado, que las fuentes documentales reproducen constantemente un esquema modelizado de constitución de las mismas y, por otro lado, al contrastar las aproximaciones resultantes del análisis de las biografías de Tschumi sobre la cantidad de hijos con las fuentes fotográficas disponibles en los álbumes familiares - locales en las que, generalmente, las familias aparecen representadas con muchos hijos (entre 6, 7 y más) de las que surgen otros cuestionamientos: en relación a las fotografías de época en donde se hallan representadas familias o grupos familiares que incluyen a otros descendientes, nietos por ejemplo; ello también rompería con la idea de pensar históricamente a las familias desde una visión anclada en el modelo clásico/nuclear/moderna. Además, ¿A qué sector socio -económico corresponden esa imágenes?, ¿Representan a familias de ámbitos rurales o urbanos en este contexto de frontera?, ¿Son representativas de las familias fundadoras de los pueblos?, etc.

Tabla 3: Número de hijos por cantidad de Familias

\begin{tabular}{|l|r|r|r|}
\hline N HuOS & N FUAS & N FUAS $\%$ N FUAS \% S/D \\
\hline 1 & 13 & $5,2 \%$ & $7,1 \%$ \\
\hline 2 & 41 & $16,5 \%$ & $22,4 \%$ \\
\hline 3 & 42 & $16,9 \%$ & $23,0 \%$ \\
\hline 4 & 28 & $11,2 \%$ & $15,3 \%$ \\
\hline 5 & 17 & $6,8 \%$ & $9,3 \%$ \\
\hline 6 & 13 & $5,2 \%$ & $7,1 \%$ \\
\hline 7 & 6 & $2,4 \%$ & $3,3 \%$ \\
\hline 8 & 8 & $3,2 \%$ & $4,4 \%$ \\
\hline 9 & 3 & $1,2 \%$ & $1,6 \%$ \\
\hline 10 & 4 & $1,6 \%$ & $2,2 \%$ \\
\hline 11 & 2 & $0,8 \%$ & $1,1 \%$ \\
\hline 12 & 3 & $1,2 \%$ & $1,6 \%$ \\
\hline 14 & 1 & $0,4 \%$ & $0,5 \%$ \\
\hline 15 & 1 & $0,4 \%$ & $0,5 \%$ \\
\hline 27 & 1 & $0,4 \%$ & $0,5 \%$ \\
\hline SIN HIJOS o S/D & 66 & $26,5 \%$ & \\
\hline Total sin hijosS/D & 183 & & \\
\hline Total general & 249 & & \\
\hline
\end{tabular}

Fuente: Tschumi (1948). Elaboración propia.

Los interrogantes anteriores nos inducen a (re)cuestionar las formas en que, desde el campo de las ciencias sociales y la historiografía, se construyeron relatos acerca de la historización de la vida familiar sin tener en cuenta "...la constitución de representaciones de objetos, en este caso la familia [y las fuentes que de ella versan], operan fuertemente como imágenes significantes hegemónicas instituidas socialmente a partir de leyes, normas, costumbres y valores predominantes donde interjuegan la experiencia individual, familiar y social de cada sujeto" (DE JONG, 2010, p.11); problemáticas que, en la actualidad, son revisitadas y abordadas desde áreas disciplinares específicas y desde miradas interdisciplinares (historia de la vida cotidiana, historia de la familia, etc.). 


\section{Conclusión. Revisitando la familias desde un interjuego entre fuente-contexto y en un territorio fronterizo}

En este artículo situamos a las familias como centro de la investigación y ello significo ponerlos en relación a diversas escalas de observación los niveles micro, sujetos: hombres y mujeres, y macro, Misiones en la región de frontera. Desde esa lógica, la reducción de la escala de observación posibilito avanzar, en parte, en el análisis de los múltiples e infinitos aspectos de la experiencia de los sujetos mediante el examen de las breves biografías, vinculando a los grupos y sujetos en las redes sociales de circulación desde sus trayectorias y desplazamientos socialmente inscriptos e instituidos para; de esta manera, divisarlos en diferentes campos/actividades/territorialidades (MILANO 2013: 56; citando a BOURDIEU) a fin de poder mostrar la significación histórica general de tales experiencias.

$\mathrm{Y}$, considerando que los relatos biográficos que evaluamos no son producto de los propios involucrados sino de un observador profesional, que actúa de intermediario, recurrimos a situar la fuente como resultado de época; en tanto narración de una "...historia aristocrática y tradicional de las ideas [y establecida desde]las clases dominantes [quienes podían]generar y producir cultura" (GUINZBURG, 2004:18); es así que sostenemos que la producción de las fuentes en una determinada sociedad está ligada, de manera directa, a las relaciones de fuerza que existen al interior de la misma, puesto que los órganos de poder las producen legitimando y acotando territorialidades del poder; en beneficio de los sectores dominantes. Sin embargo, la inclusión de las biografías individuales por el autor, realizada consciente o inconscientemente, se constituye en un hecho excepcional que transgrede el paradigma vigente y se convierte en un instrumento valorado por nosotros en y para la recuperación de las voces los sujetos implicados directamente en el desarrollo de los acontecimientos; para la construcción de la historia desde las perspectivas en y desde el presente.

Entendemos que durante la etapa colonizadora de la primera mitad del siglo XX, en el espacio regional interactuaban distintos factores que hicieron posible la ocupación y el poblamiento, puesto que tanto los grupos nativos como las comunidades foráneas funcionaron y respondieron en torno a las lógicas y normativas local/nacional/internacional de la región de frontera; visualizando a Misiones como territorio nucleador de las relaciones sociales en tanto territorialidad y territorialización de la práctica de los sujetos que la habitaron. Las familias se constituyeron en grupos fundamentales de contención social, sea individual y/o colectiva, y eran poderosas en tanto aseguraban y acumulaban riqueza económica dentro del grupo familiar; proyectando alianzas entre sí mediante una trama de vínculos de parentesco, amistad y paisanaje que garantizaban la construcción y expansión del poder de las mismas.

No obstante, entendemos que en esa red de relaciones, el poder no se concentró solo en los sectores de élite, poseedores de mayor riqueza, prestigio o linaje, o cualquier otro atributo o combinación de los mismos que sirva para identificarlos, sino que ciertas dosis de poder estaba también encarnado en los subgrupos, en este caso a manera de "élites secundarias" o "sub - élites" que se encontraban vinculados a dichos sectores y que ejercieron una cuota de poder imprescindible para el funcionamiento de la sociedad (QUIÑONES, 2009). Es así que en esos intersticios que las familias de establecidos, criollas/correntinas, fueron reposicionándose en la franja de este subgrupo, pues se relacionaban con el grupo que conducía los gobiernos y las instituciones locales y, a través de estos vínculos, se reinsertaron en la sociedad misionera; afianzando su poder desde la acumulación de riquezas en tanto capital económico como cultural. Esto es lo que logramos demostrar en este artículo, en el que desarrollamos una ruta del proceso colonizador, fijando el punto de partida en el accionar de los establecidos, indios, negros y criollos, como componentes y protagonistas necesarios de ser visibilizados, reafirmando y demostrando la existencia de un territorio habitado, para 
comprender el marco contextual en el que se insertaron las diversas comunidades de inmigrantes, europeas y asiáticas.

$\mathrm{Y}$ desde ese enfoque, la fortaleza de este trabajo reside en invertir la mirada para aproximarnos al estudio de la colonizacion y el poblamiento de Misiones, acotando la perspectiva analitica local/regional y la escala de observacion familias y sujetos, a partir de los datos fragmentarios y parciales que las fuentes ofrecen, focalizada en la muestra de pobladores aportada por Tschumi y la informacion indiciaria reportada por los anuarios de TNM de 1923, 1938 y 1943. Desde lo conceptual la atención se centro en definr a la familia o las configuraciones familiares en tanto red virtual que traza vínculos y estrategias de articulación de actividades y acciones en el territorio habitado y vivido por los sujetos y se sostiene en vínculos que subrayan relaciones de parentesco hacia el interior de las mismas pero que, al mismo tiempo, se expanden articulando relaciones entre las familias mediante conexiones que integran lazos de solidaridad y de amistad. En esa trama, los indios y los negros fueron totalmente marginados y excluidos ya que, aunque parte de ellos se insertaron laboralmente a determinadas actividades económicas; se perdieron como grupo social al estar imposibilitados para acumular riquezas y, por lo tanto, impedidos para construir poder. Una parte de la población aborigen sobrevivió alejada y pudo mantener su cultura relativamente intacta y otra parte fue compulsivamente integrada a través del mestizaje mientras que los negros se recluyeron en las periferias conformando barriadas. Y, finalmente, son los inmigrantes europeos y asiáticos los outsiders incorporados a la sociedad nacional/regional/local, complejizando acentuadamente la heterogeneidad social preexistente en la estructura social. Respecto de estos grupos, intentamos redescubrirlos en espacios acotados al interior de la región de frontera evidenciando la diversidad de procedencias e ilustrando un caso específico; a fin de replantear y poner en el tapete una nueva discusión en relación al alcance de los distintos modelos de colonización: estatal, privada y espontánea.

\section{Bibliografía}

ARELLANO, Diana y OVIEDO, Norma: Territorialidades vividas, dinámicas fronterizas en la región misionera. Revista Intellector, Dossier, CENEGRI (Centro de Estudos em geopolitica \& relacoes internacionais), v. 13, n. 26, p. 111-123, 2017. ISSN 18071260. Disponible en: http://www.cenegri.org.br/intellector/ojs2.4.3/index.php/intellector/issue/view/27/showToc

ARENHARDT, Elida. Don Adolfo Schwelm y su proyecto colonizador. Posadas, Instituto Superior del Profesorado Antonio Ruiz de Montoya, 2003. III Jornadas sobre Poblamiento, Colonización e Inmigración de Misiones.

ARENHARDT, Elida. El sistema Waldhufendorf organiza el paisaje rural de Colonia Eldorado (1924-1948). Posadas, Instituto Superior del Profesorado Antonio Ruiz de Montoya, 2005.IV Jornadas sobre Poblamiento, Colonización e Inmigración de Misiones.

CAMBAS, Aníbal: Historia Política e Institucional de Misiones. Buenos Aires, Talleres Gráficos Kraft Ltda., 1945.

CARBONARI, Maria Rosa: População, Fronteira é Família. A região de Rio Cuarto no período colonial tardio. Niterói, Universidade Fluminense, 2001. p. 262. (Tese de Doutorado em História, Área de concentração: História Moderna e Contemporânea). 
DE JONG, Eloísa y otros. Familia: Representaciones y significados. Una lucha entre semejanzas y diferencias. Entre Ríos: Universidad Nacional de Entre Ríos, Editorial Espacio, 2010 .

DEVOTO, Fernando y MADERO, Marta. Historia de la vida privada en la Argentina. La Argentina plural: 1870-1930. Argentina, Grupo Santillana de Ediciones S. A., 1999. Tomo II. Edic. digital ISBN: 950-511-558-X.

DEVOTO, Fernando. Historia de la inmigración en la Argentina. Buenos Aires, Editorial Sudamericana, 2009.

ELIAS, N. Y SCOTSON, J. Os estabelecidos e os outsiders. Rio de Janeiro J. Zahar, 2000.

ETORENA, Alba C. y FREAZA, C. Historia de Posadas. Posadas: Talleres gráficos EXTRA, 2010.

FERNANDEZ RAMOS, Raimundo. Apuntes Históricos sobre Misiones. Madrid: Espasa Calpe, 1928.

FERNANDEZ, Sandra. Más allá del territorio: la historia regional y local como problema. Discusiones, balances y proyecciones. Rosario: Prohistoria Ediciones, 2007.

GALLERO, Cecilia. La colonización privada en Misiones y el accionar de la Compañía Eldorado (1919-1959). Revista Folia Histórica del Nordeste, Resistencia, No 17, pp. 63-84, 2008. Disponible en:file:///C:/Users/Acer/Downloads/3449-11098-1-PB.pdf.

GUINZBURG, Carlo. Tentativas: Rosario, Prohistoria, 2004.

LAMBORGHINI, E., MARTINO M.C. y MARTINEZ PERIA, J.F. (Comp.). Actas de las Quintas Jornadas del Geala. Estudios Afro-latinoamericanos 3. - 1a. ed. - Ciudad Autónoma de Buenos Aires: Ediciones del CCC (Centro Cultural de la Cooperación Floreal Gorini), 2017. Libro digital, PDF. Archivo Digital: online ISBN 978-987-3920-36-3

LEVINTON, Norberto y SNIHUR, Esteban: Misiones. Territorio de Fronteras (1609-1895). Buenos Aires: Yacyreta, Contratiempo Ediciones, 2015.

MEDINA, Ana Belén. La revista 'Cosas y hechos de Misiones' desde una perspectiva de género. Resistencia, XXXVIII Encuentro de Geohistoria Regional y VII Simposio sobre el actual del conocimiento del Gran Chaco Meridional "Región y políticas públicas”, 2018.

MEDINA, Ana Belén. Las mujeres de las revistas de los 50`en Misiones: Género, Alteridad e Identidad. ANAIS IV GEOFRONTEIRAS - Grande Dourados, Universidade Federal da Grande Dourados, 2017. - ISBN 2362 3365. Disponible en: http://www.geofronteras.com/p/anais_22.html

MILANO, Adriana N. El género biográfico y sus aportaciones metodológicas: el impacto en la historiografía argentina reciente. Historiografías: revista de historia y teoría, No . 6, 2013. p. 53-76. ISSN-e 2174-4289. 
OVIEDO, Norma y ALCARAZ, Jorge R. Representaciones de las actividades económicas en el Territorio Nacional de Misiones (1930 - 1950). Revista la Rivada. Investigaciones en Ciencias Sociales Edición semestral, Posadas, Vol. 2 N³3, pp. 1-13, 2014. ISSN 2347-1085, Revista electrónica de la Sec. de Investigación y Postgrado-FHyCS-UNaM. Disponible en:http://www.larivada.com.ar/attachments/article/87/larivada-n3--dossier-alcarazoviedo.pdfwww.larivada.com.ar

OVIEDO, Norma y COSSI, Carla. Historia de Mujeres Misioneras. Posadas: EDUNaM (Editorial Universitaria de la Universidad Nacional de Misiones), 2019.

OVIEDO, Norma. La ocupación paraguaya en la región misionera argentina y el origen de la Trinchera. Posadas, Facultad de Humanidades y Ciencias Sociales, Universidad Nacional de Misiones (UNaM), Inédito. 1994. pp. 250. (Tesis de Licenciatura en Historia).

OVIEDO, Norma. Relaciones comerciales y conflictos fronterizos. Siglo XIX, Misiones en la red platina. Posadas: EDUNaM (Editorial Universitaria de la Universidad Nacional de Misiones), 2014.

QUINONES, Mercedes. Familia y red social. La elite salteña en las primeras décadas del siglo XIX. San Fernando del Valle de Catamarca, Universidad Nacional de Catamarca, 2009. p. 1-26. (X Jornadas Argentinas de Estudios de Población)

SCHIAVONI, Ángela. Fragmentos para armar Historias. Revista Estudios Regionales. Posadas, Número Especial 20 Aniversario del Centro de Estudios Histórico-Culturales “Ángela A. Perié de Schiavoni, 2002.SCHIAVONI, Gabriela y GALLERO. Colonización y ocupación no planificada. La mercantilización de la tierra agrícola en Misiones (1920-2000). Revista Travesía, Vol. 19, Nº 1,Enero-Junio 2017. pp. 77-106.ISSN 0329-9449 -

SCHIAVONI, OVIEDO, JAQUET: Tras los pasos de los guaraníes perdidos. En otra historia. Nuevos diálogos entre historiadores y educadores en torno a la construcción y enseñanza de la historia de Misiones. Posadas, EDUNaM (Editorial Universitaria de la Universidad Nacional de Misiones), 2001.

SCHVORER, E. L. Misiones. Estructura social agraria, estado y conflictos sociales. Las circunstancias de una historiografía regional. Historia politica.com.Programa Buenos Aires de Historia Política del siglo XX, 2011. pp. 1-24.Disponible en: http://historiapolitica.com/datos/biblioteca/territoriosaprovincias_schover.pdf

TORRADO, Susana. Historia de la familia argentina moderna (1870-2000). Buenos Aires: La Flor, 2003.

\section{Fuentes}

BORDON, Arturo y VALDOVINOS, Elías. Guía General de Misiones. Descripción geográfica, Histórica, Política, Económica, Cultural y Social de Misiones. Posadas-Misiones, Ed. América, 1943.

HASSEL, Hermann. Misiones, almanaque-guía para el año 1938. Posadas-Misiones, Imprenta Foto Moderna, 1938. 
LIBRO AZUL DE MISIONES 1935/36. Guía del Territorio Nacional (S/D).

NEWTON, Jorge. Misiones Oro Verde y Tierra Colorada. Buenos Aires, El Gráfico Imprenta, 1951.

PRESIDENCIA DE LA NACION. La Nación Argentina justa, libre y soberana. Plan de Gestión de Gobierno (1950-1955). Buenos Aires, Edición de divulgación, $3^{\text {ra. }}$ Edición, Taller Gráficos de Peuser, 1950.

SOSA, Atanasio. Guia General de Misiones. Posadas-Misiones, s/d, 1923.

TSCHUMI, Eric. Tierra Colorada. Síntesis agraria, industrial, comercial, cultural, turística y biográfica del Territorio Nacional de Misiones. Bs. As., Talleres Gráficos Alemann y Cia. S.A.G.I, 1948.

\section{Nota biográfica:}

Norma Oviedo - Mestre em Historia (PUCRS). Docente e Investigadora (UNaM), Especialista en Historia Regional y local y autora de artículos y publicaciones, entre ellas los siguientes libros: Relaciones Comerciales y Conflictos Fronterizos S. XIX. Misiones en la red Platina (2014), Historia de Cerro Cora (2018) e Historia de Mujeres Misioneras (2019). Integrante del Programa de Investigaciones Interdisciplinarias sobre regiones de frontera (UNaM) y del Grupo de Estudos sobre Fronteira, Territorio e Ambiente (UNIOESTE).

Mail: ovinor77@gmail.com 